\title{
Effects of Cold Jet Atmospheric Pressure Plasma on the Structural Characteristics and Immunoreactivity of Celiac-Toxic Peptides and Wheat Storage Proteins
}

\author{
Fusheng Sun ${ }^{1}$, Xiaoxue Xie ${ }^{1}$, Yufan Zhang ${ }^{1}$, Jiangwei Duan ${ }^{2}{ }^{-}$, Mingyu Ma ${ }^{2}$, Yaqiong Wang ${ }^{1}$, \\ Ding Qiu ${ }^{1}$, Xinpei $\mathrm{Lu}^{2}$, Guangxiao Yang ${ }^{1, *}$ and Guangyuan $\mathrm{He}^{1, *}$ \\ 1 The Key Laboratory of Molecular Biophysics of Chinese Ministry of Education, The Genetic Engineering \\ International Cooperation Base of Chinese Ministry of Science and Technology, College of Life Science and \\ Technology, Huazhong University of Science and Technology, Wuhan 430074, China; \\ fufu4567@126.com (F.S.); xiexiaoxue_Cecilia@163.com (X.X.); zhangyufan1108@126.com (Y.Z.); \\ wangyaqiongyou@126.com (Y.W.); qiuding1989@outlook.com (D.Q.) \\ 2 State Key Laboratory of Advanced Electromagnetic Engineering and Technology, School of Electrical and \\ Electronic Engineering, Huazhong University of Science and Technology, Wuhan 430074, China; \\ duanjiangwei@foxmail.com (J.D.); mmyhfut@163.com (M.M.); luxinpei@hotmail.com (X.L.) \\ * Correspondence: ygx@hust.edu.cn (G.Y.); hegy@hust.edu.cn (G.H.); Tel.: +86-27-87792271 (G.Y. \& G.H.); \\ Fax: +86-27-87792272 (G.Y. \& G.H.)
}

Received: 13 December 2019; Accepted: 20 January 2020; Published: 4 February 2020

\begin{abstract}
The present research reported the effects of structural properties and immunoreactivity of celiac-toxic peptides and wheat storage proteins modified by cold jet atmospheric pressure (CJAP) plasma. It could generate numerous high-energy excited atoms, photons, electrons, and reactive oxygen and nitrogen species, including $\mathrm{O}_{3}, \mathrm{H}_{2} \mathrm{O}_{2}, \bullet \mathrm{OH}, \mathrm{NO}_{2}{ }^{-}$and $\mathrm{NO}_{3}{ }^{-}$etc., to modify two model peptides and wheat storage proteins. The Orbitrap HR-LC-MS/MS was utilized to identify and quantify CJAP plasma-modified model peptide products. Backbone cleavage of QQPFP and PQPQLPY at specific proline and glutamine residues, accompanied by hydroxylation at the aromatic ring of phenylalanine and tyrosine residues, contributed to the reduction and modification of celiac-toxic peptides. Apart from fragmentation, oxidation, and agglomeration states were evaluated, including carbonyl formation and the decline of $\gamma$-gliadin. The immunoreactivity of gliadin extract declined over time, demonstrating a significant decrease by $51.95 \%$ after $60 \mathrm{~min}$ of CJAP plasma treatment in vitro. The CJAP plasma could initiate depolymerization of gluten polymer, thereby reducing the amounts of large-sized polymers. In conclusion, CJAP plasma could be employed as a potential technique in the modification and reduction of celiac-toxic peptides and wheat storage proteins.
\end{abstract}

Keywords: cold jet atmospheric pressure plasma; reactive oxygen and nitrogen species; backbone cleavage; hydroxylation; carbonyl formation

\section{Introduction}

Gluten proteins in wheat (Triticum aestivum L.) are a type of storage protein-containing gliadins and glutenins, which are responsible for the rheological and viscoelastic properties of wheat dough [1]. Gluten proteins contain abundant proline (Pro) and glutamine (Gln) residues, which can cause high resistance of gluten peptides to be hydrolyzed, a property that contributes to the gluten-related immunogenic nature of celiac disease (CD) patients [2]. The degradation of gluten proteins can decrease their immunological and toxic properties. To date, some biological, chemical, and physical approaches have been applied to reduce toxicity of these proteins to patients with CD. Biological strategies include downregulation of gliadin expression by CRISPR-Cas9 to produce low-gluten wheat 
lines with an average reduction of $66.7 \%$ and $61.7 \%$ with regard to R5 and G12 antibody reactivity [3]. For biochemical processing, usage of food-grade microbial transglutaminase (mTG) with lysine ethyl ester is able to modify gliadin peptides, which inhibits the ability of gluten to trigger the specific human immune response in vitro [4]. Huang et al. (2017) found a metal-catalyzed oxidation system can cause the modification and elimination of hordein, leading to the decrease of immunoreactivity of hordein [5].

Although enzymatic and chemical methods possess high efficiency in the modification of macromolecular compound, shortcomings of these techniques are concerned in points of higher cost, wastewater pollution and food safety etc. Physical techniques could make up for these deficiencies of enzymatic and chemical modifications [6]. The high temperature treatment modifies protein through denaturation and formation of inter/intramolecular bonds, which consequently resulted in specific epitopes unrecognizable by antibody [7]. Also, it has been reported that ozone, excited atoms, ions and electrons can be considered as efficient species because they can act as strong oxidizing agents for the object without leaving any residues [8]. According to this principle, cold plasma is regarded as an emerging non-thermal technique to modify the characteristics of gluten in wheat flour [9]. Cold plasma, regarded as the source of reactive oxygen and nitrogen species (RONS), is an ionized gas consisting of a variety of types of active species, such as singlet oxygen, ozone, excited molecular nitrogen, and other electrons or ions [10]. Exploitation of plasma has been widely researched in nonfood areas, such as the inactivation of bacteria, wound healing, tooth bleaching, and cancer therapy [11-14]. However, whether it can modify wheat gluten proteins to reduce the toxicity of celiac disease has rarely been investigated.

At present, the common method for quantification of food prolamins is based on antibodies against the epitopes Gln-Gln-Pro-Phe-Pro (QQPFP) and Pro-Gln-Pro-Gln-Leu-Pro-Tyr (PQPQLPY) [5]. Therefore, two model celiac-toxic peptides, QQPFP-repetitive domain in the $\gamma$-type, $\alpha$-type and $\omega$-type of prolamins in barley, rye and wheat, PQPQLPY-repetitive sequence in 33-mer peptide, were selected for plasma modification in our study [15]. Arentz-Hansen et al. (2002) previously stated that the toxicity mechanism of QQPFP sequence to CD patients may be due to its involvement in triggering T-cell activation after the deamidation of specific glutamine residues [16]. Furthermore, three previously identified celiac-specific T-cell epitopes play an important role in T-cell proliferation, namely, PQPQLPYPQ, PFPQPQLPY and PYPQPQLPY, all of which contain heptapeptide PQPQLPY [5]. In addition, exposure of Pro, Gln and phenylalanine (Phe) provides an important recognition site for G12 or R5 antibody, or stimulates the T-cell response [17]. Consequently, wheat gliadins in food containing those epitopes should be modified before their consumption in CD patients [18].

The objective of this study was to investigate the understanding of impacts of CJAP plasma on the structural properties and immunoreactivity of celiac-toxic peptides and wheat storage proteins in vitro. The effects of fragmentation at Pro and Gln and hydroxylation at Phe and tyrosine (Tyr) on celiac peptides-QQPFP and PQPQLPY, modifications and depolymerization behavior of gluten proteins, along with their immunoreactivity against R5 antibody after CJAP plasma treatment, were examined in this research.

\section{Results}

\subsection{Experiment Setup, Discharge, Current and Optical Emission Spectrum (OES) Measurements}

The schematic diagram of experiment setup is shown in Figure 1. The celiac-toxic peptides and wheat storage protein samples in 96-well plate (200 $\mu \mathrm{L}$ per sample) were modified by the special CJAP plasma. The discharge gas consisted of helium at a flow rate of $2 \mathrm{~L} / \mathrm{min}$ and air at a flow rate of $10 \mathrm{~mL} / \mathrm{min}$. The distance from the surface of slurry to jet nozzle was $10 \mathrm{~mm}$. The samples were modified by CJAP plasma at different time points $(0,5,10,20,30$, and $60 \mathrm{~min})$. 


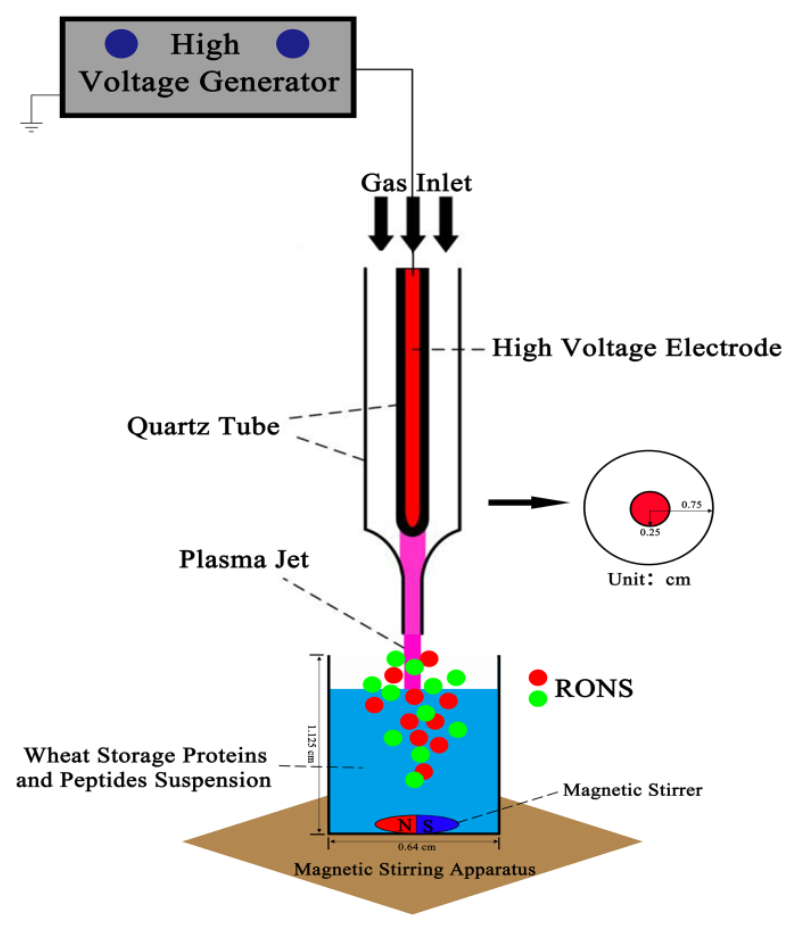

Figure 1. Schematic diagram of the plasma setup. The model peptides and gluten proteins in the 96-well plate were treated using a cold jet atmospheric pressure (CJAP) plasma jet.

The wave-forms of set voltage and single current of CJAP plasma were shown in Figure 2A. The peak-to-peak set voltage was $35 \mathrm{kV}$ and frequency was $1 \mathrm{kHz}$. The OES of plasma were presented in Figure 2B, which were detected using an Ocean optics spectrometer. The emission lines of $\mathrm{N}_{2}, \mathrm{~N}_{2}{ }^{+}$, $\mathrm{NO}, \bullet \mathrm{OH}, \mathrm{O}$, and $\mathrm{He}$ can be found when the discharge gas is air [19].
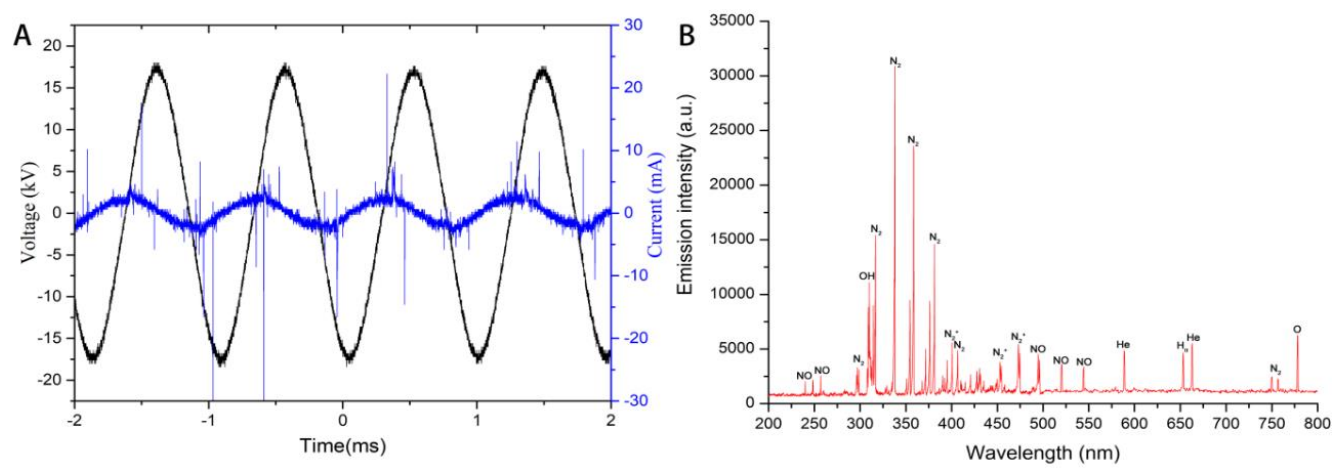

Figure 2. The waveforms of applied voltage and current (A) and the optical emissions spectra (OES) of the CJAP plasma jet (B).

\subsection{Generation of Several RONS Induced by CJAP Plasma}

In plasma processes, active species such as radicals and ions induced by the plasma play a dominant role. To study the effects of various RONS on plasma modification of two model peptides and gliadin, the contents of $\mathrm{H}_{2} \mathrm{O}_{2}, \mathrm{OH}$ radicals, $\mathrm{O}_{3}$ and $\mathrm{NO}_{2}{ }^{-}+\mathrm{NO}_{3}{ }^{-}$were determined in this part.

In order to understand the acidity and alkalinity of samples after treating the plasma, the $\mathrm{pH}$ value was determined. The $\mathrm{pH}$ value results showed a longer plasma treatment time correlated with a greater decline in $\mathrm{pH}$ value. From Figure $3 \mathrm{~A}$, it can be seen that the $\mathrm{pH}$ value decreased from 6.7 at $0 \mathrm{~min}$ to 2.2 after $60 \mathrm{~min}$. 

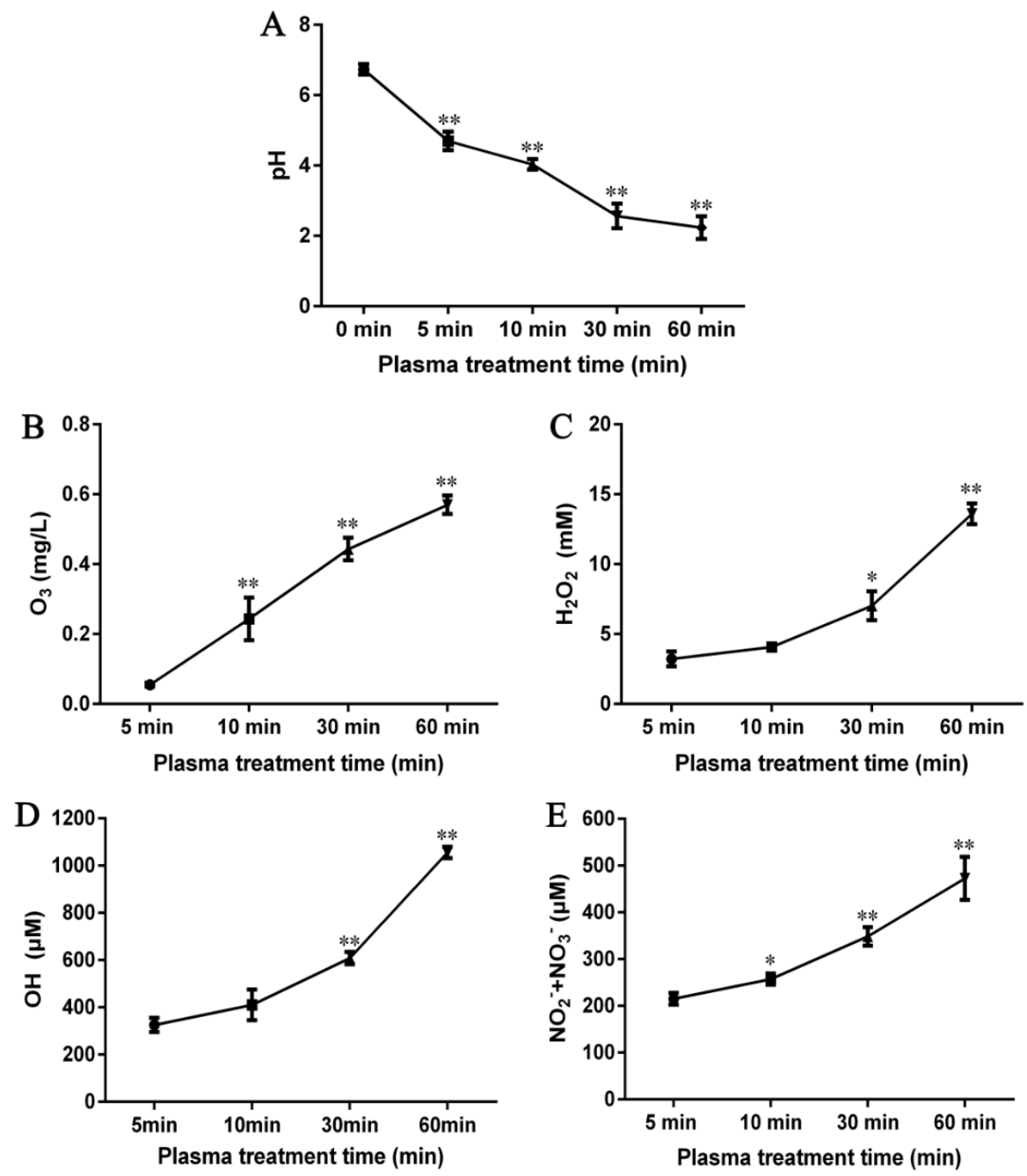

Figure 3. The $\mathrm{pH}$ value (A) and concentrations of $\mathrm{O}_{3}(\mathbf{B}), \mathrm{H}_{2} \mathrm{O}_{2}(\mathbf{C}), \bullet \mathrm{OH}(\mathbf{D})$, and total $\mathrm{NO}_{2}{ }^{-}$and $\mathrm{NO}_{3}{ }^{-}$(E) in CJAP plasma with treatment times of $5 \mathrm{~min}, 10 \mathrm{~min}, 30 \mathrm{~min}$, and $60 \mathrm{~min}$. Data are presented as means $\pm \mathrm{SE}(n=3)$ in the $\mathrm{pH}$ and reactive oxygen and nitrogen species (RONS) detection assays. Asterisks represent statistically significant differences from $5 \min \left({ }^{*} p<0.05,{ }^{* *} p<0.01\right)$.

Ozone is reported to selectively react with substrates by electrophilic attack and cycloaddition, while decomposing to produce $\mathrm{OH}$ radicals as another non-selective oxidant [20,21]. For a better understanding of the changes in ozone content following plasma initiation, results of the $\mathrm{O}_{3}$ content were measured (Figure 3B), which presented a time-dependent increase, with significant increase $(p<0.01)$ at $10 \mathrm{~min}$ over control. It was found that the concentration of $\mathrm{O}_{3}$ of the treated samples are $0.06 \mathrm{mg} / \mathrm{L}, 0.24 \mathrm{mg} / \mathrm{L}, 0.45 \mathrm{mg} / \mathrm{L}$, and $0.58 \mathrm{mg} / \mathrm{L}$ at $5 \mathrm{~min}, 10 \mathrm{~min}, 30 \mathrm{~min}$, and $60 \mathrm{~min}$ of plasma treatment, respectively.

$\mathrm{H}_{2} \mathrm{O}_{2}$ was considered to be another oxidizing agent and it was selected to be detected in this paper [22]. From Figure 3C, increase in $\mathrm{H}_{2} \mathrm{O}_{2}$ concentration was dependent on treatment time within $60 \mathrm{~min}$, with the biggest increase from 30 to $60 \mathrm{~min}$. We can see that the $\mathrm{H}_{2} \mathrm{O}_{2}$ content of the treated samples expanded from $3.23 \mathrm{mM}$ at $5 \mathrm{~min}$ to $13.60 \mathrm{mM}$ at $60 \mathrm{~min}$.

For the most reactive form of $\mathrm{ROS}, \mathrm{OH}$ radicals can undergo various types of reactions with amino acid side chains and peptide backbone [23]. Figure 3D shows that the pattern of change in $\bullet \mathrm{OH}$ content was similar to that of $\mathrm{H}_{2} \mathrm{O}_{2}$. A significant $(p<0.01)$ increase occurred at $30 \mathrm{~min}$, followed by a further increase at $60 \mathrm{~min}(p<0.01)$. The $\bullet \mathrm{OH}$ content was $325.53 \mu \mathrm{M}$ at $5 \mathrm{~min}, 410.31 \mu \mathrm{M}$ at $10 \mathrm{~min}$, $608.30 \mu \mathrm{M}$ at $30 \mathrm{~min}$ and $1055.10 \mu \mathrm{M}$ at $60 \mathrm{~min}$. 
High oxidation features could also be possessed by reactive nitrogen species. To demonstrate whether nitrogen oxides were generated during plasma treatment to aid in modification and oxidation of proteins and peptides, the total $\mathrm{NO}_{2}{ }^{-}$and $\mathrm{NO}_{3}{ }^{-}$contents were measured. Figure $3 \mathrm{E}$ shows that the total contents of $\mathrm{NO}_{2}{ }^{-}$and $\mathrm{NO}_{3}{ }^{-}$increased rapidly to $215.21 \mu \mathrm{M}$ at $5 \mathrm{~min}$ and then further increased at $60 \mathrm{~min}$, reaching $472.83 \mu \mathrm{M}$.

\subsection{Oxidation and Hydroxylation Gives Rise to P1 P7 after CJAP Plasma Treatment}

Under non-plasma treatment conditions, the major peaks on the chromatograms were two original peptides, QQPFP (Supplementary Figure S1A) and PQPQLPY (Supplementary Figure S1B). After CJAP plasma modification, the peak intensities of two model peptides decreased and were almost undetectable after $60 \mathrm{~min}$ of treatment. With plasma processing, several new peaks appeared, mainly P1 P7. Fragmentation continued with continued treatment, but after $60 \mathrm{~min}$, most of peaks had disappeared and less peptide was detected in columns.

\subsection{Modification of Specific Pro, Gln, Phe, and Tyr Residues Leads to Degradation of the Model Peptides}

The MS/MS spectra of QQPFP $(616.27 \mathrm{~m} / \mathrm{z})$ and PQPQLPY $(842.44 \mathrm{~m} / \mathrm{z})$ exhibited several fragmentation ions relating to $\mathrm{b}, \mathrm{x}, \mathrm{y}$ and $\mathrm{z}$ ions in the process of collision-induced dissociation (Figures 4A and 5A). For oxidation products, including P1, P2, and P6, there was a mass shift of $-30 \mathrm{~m} / \mathrm{z}$ for several $y$ and $b$ ions, corresponding to the formation of 2-pyrolidone at specific Pro residues on peptides with the loss of $-\mathrm{COOH}(-45 \mathrm{~m} / \mathrm{z})$ and subsequent addition of $\mathrm{O}(+16 \mathrm{~m} / \mathrm{z})$ linked to a double bond $(-1 \mathrm{~m} / \mathrm{z}$ ) (Figure 4B,C and Figure $5 \mathrm{C}$ ). In their hydroxylation products, namely, P3 and P5, the y2, y3, and y5 (only for P5) fragment ions showed an increase of $16 \mathrm{~m} / \mathrm{z}$, relevant to the addition of a hydroxyl group on the aromatic ring of peptides (Figures 4D and 5B). Similarly, P4 displayed a mass shift of $+32 \mathrm{~m} / \mathrm{z}$ for the $\mathrm{y} 1, \mathrm{y} 2$ and $\mathrm{y} 3$ fragment ions, suggesting that two hydroxyl groups were added to the benzene ring of specific pentapeptide (Figure $4 \mathrm{E}$ ).
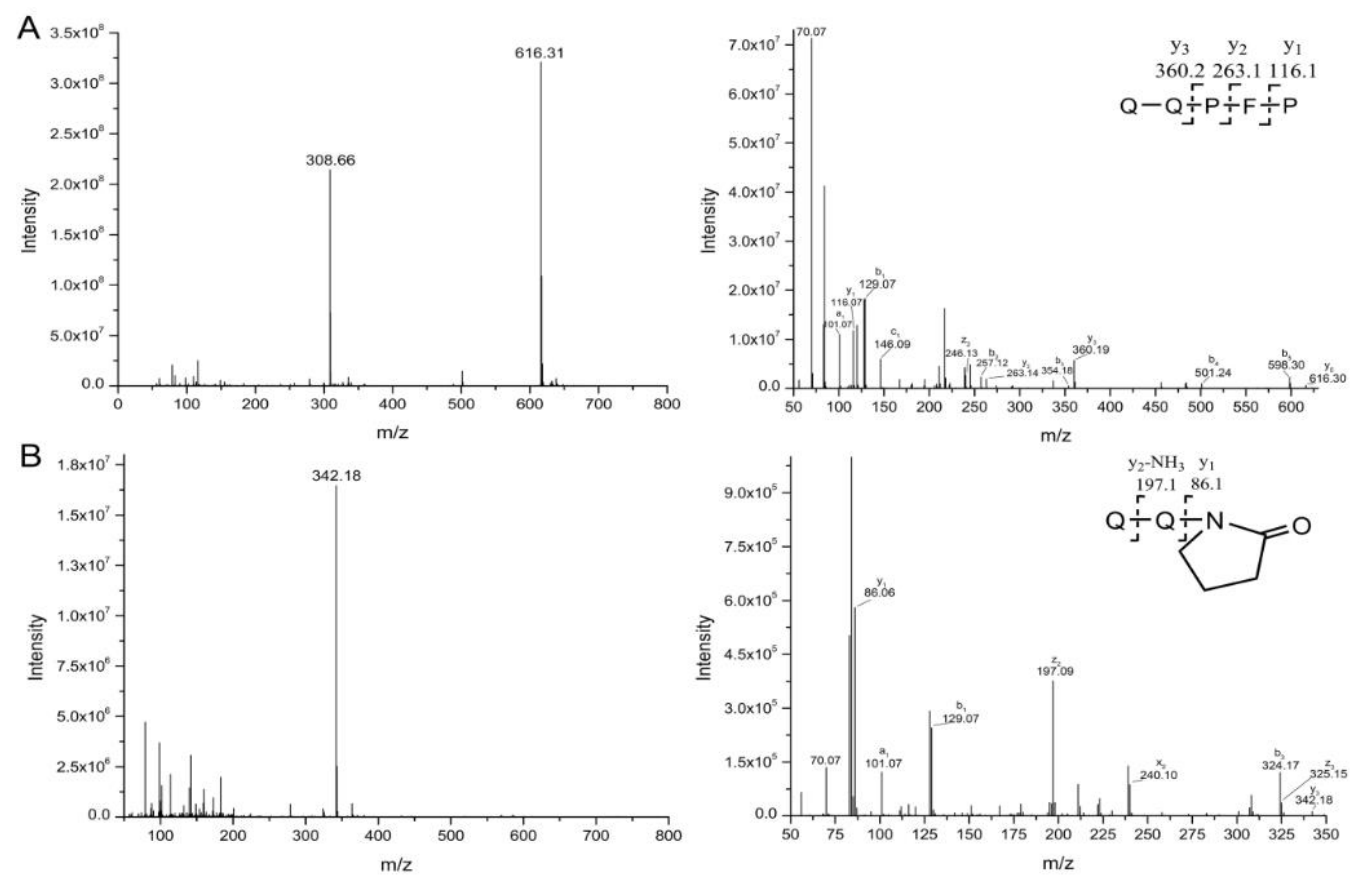

Figure 4. Cont. 

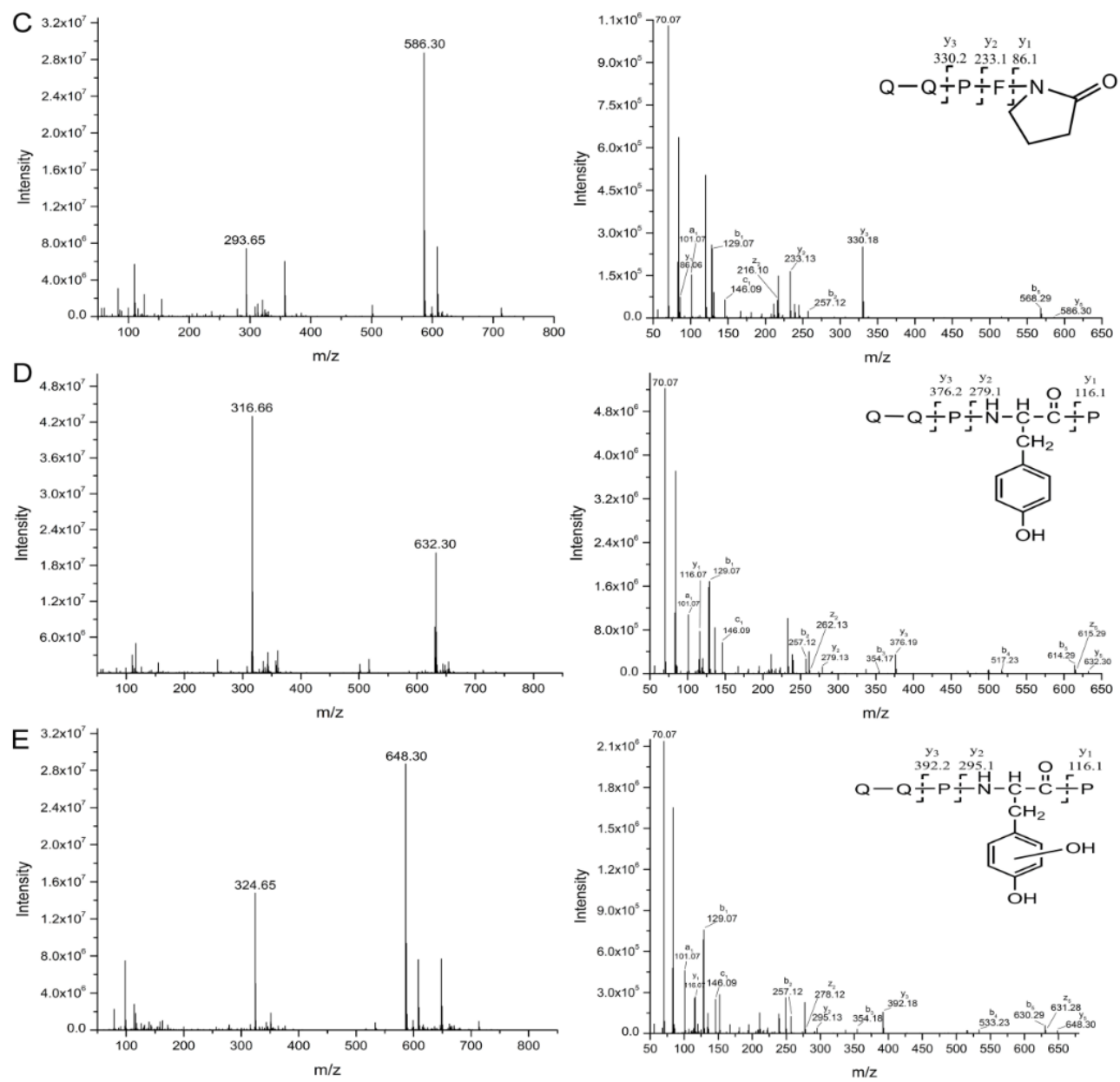

Figure 4. Full-scan mass spectrometry (MS) and representative MS/MS spectra of QQPFP and its products (P1 P4) during plasma treatment, showing evidence for $\bullet \mathrm{OH}$-mediated modification. In each panel, the left spectrum shows the full scan, while the right spectrum shows the fragment ions. The $b$ and $y$ ions originated from preferential cleavage at the $\mathrm{N}$-terminus and C-terminus of specific amino acid residues during collision-induced dissociation, respectively. (A) Original peptide $(616.3 \mathrm{~m} / \mathrm{z}$ ); (B) product $1(342.2 \mathrm{~m} / \mathrm{z})$; (C) product $2(586.3 \mathrm{~m} / \mathrm{z})$; (D) product $3(632.3 \mathrm{~m} / \mathrm{z})$; (E) product $4(648.3 \mathrm{~m} / \mathrm{z})$.

After plasma processing of original peptides, the Orbitrap HR-LC-MS/MS distinguished products P1, P2, P6 (Figure 6B,C and Figure 7C), in which Pro residues were attacked, as well as P3, P4 and P5 (Figures 6D and 7B), with the addition of hydroxyl groups on phenyl ring of Phe, leading to one or two +16-Da mass shifts. QQPFP gave rise to CJAP plasma-induced oxidation products at $m / z 342.12$ (P1) and $m / z 586.30(\mathrm{P} 2)$, as well as hydroxylation products at $m / z 632.30$ (P3, hydroxyphenylalanine) and $m / z 648.30$ (P4, dihydrophenelalanine, DOPA), while PQPQLPY generated products at $m / z$ 858.43 (P5), $m / z 311.17$ (P6) and $m / z 214.11$ (P7) (Figures 4 and 5). 

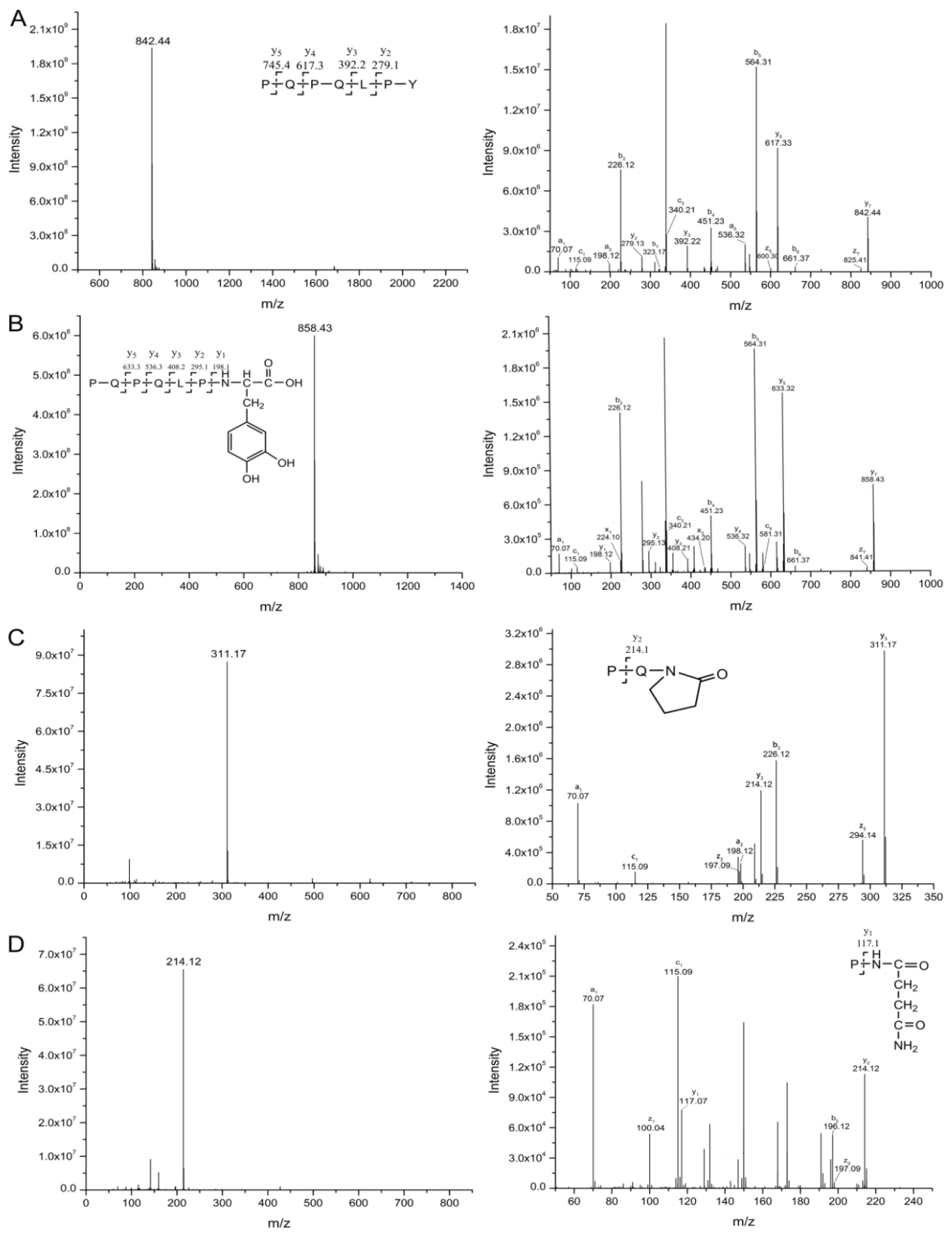

Figure 5. Full-scan MS and representative MS/MS spectra of PQPQLPY and its products (P5 P7) during plasma treatment, showing evidence for $\bullet \mathrm{OH}$-mediated modification. In each panel, the left spectrum shows the full scan, while the right spectrum shows the fragment ions. The $\mathrm{b}$ and $\mathrm{y}$ ions originated from preferential cleavage at the $\mathrm{N}$-terminus and $\mathrm{C}$-terminus of specific amino acid residues during collision-induced dissociation, respectively. (A) Original peptide $(842.4 \mathrm{~m} / \mathrm{z})$; (B) product $5(858.4 \mathrm{~m} / \mathrm{z})$; (C) product $6(311.7 \mathrm{~m} / \mathrm{z})$; (D) product $7(214.1 \mathrm{~m} / \mathrm{z})$. 


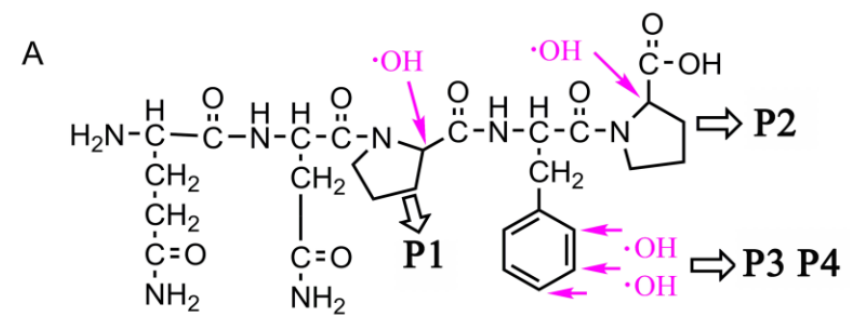

B

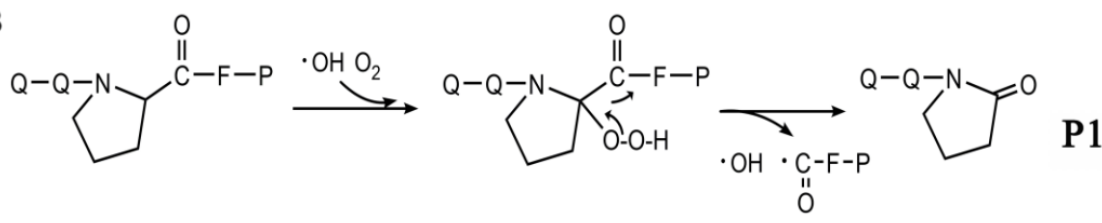

C

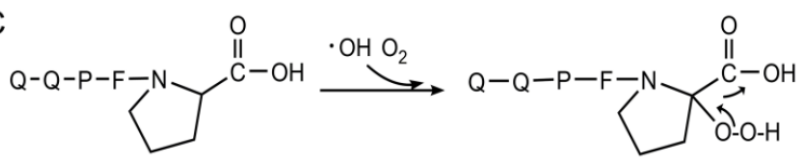<smiles>CC1C[C@@H](OOP=PO[P-]2CCCC2=O)C(=O)O1</smiles>
P2

D

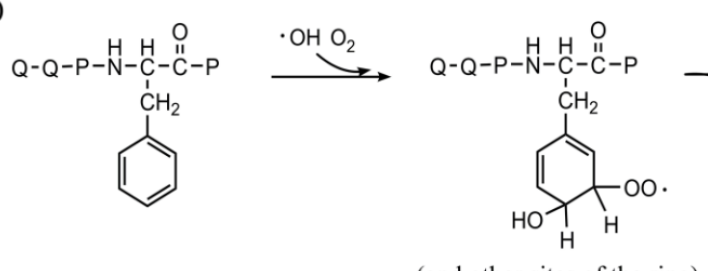

(and other sites of the ring)

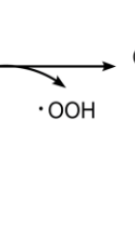<smiles>COPNC(Cc1ccc(O)cc1)C(=O)P</smiles>

P3<smiles>O=C(P)CC(Cc1ccc(O)c(O)c1O)C(=O)OOOO</smiles>

P4

Figure 6. Structures of the celiac-toxic peptide QQPFP and its CJAP plasma-modified products referred to in this research (P1 P4), which were detected by Orbitrap HR-LC-MS/MS. (A) Structural changes in QQPFP during CJAP plasma treatment. The arrow shows the sites that were attacked at the intermediate region and C-terminus of the specific pentapeptide in this study. (B) The reaction pathway of $\mathrm{P} 1$ formation involved in $\bullet \mathrm{OH}$ attack at the Pro residue in the intermediate region. (C) The reaction pathway of P2 formation associated with $\bullet \mathrm{OH}$ attack at the Pro residue in the C-terminus. (D) P3 and $\mathrm{P} 4$ were formed through the reaction involved in $\bullet \mathrm{OH}$ attack at the benzene ring of Phe, followed by a reaction with $\mathrm{O}_{2}$ and, subsequently, elimination of $\bullet \mathrm{OOH}$.

As shown in Supplementary Figure S2A, plasma treatment exceeding 10 min resulted in detectable Pro fragmentation and hydroxylation of Phe in the peptide. After 10 min of plasma treatment, 40.21\% of QQPFP and $66.73 \%$ of PQPQLPY remained intact, and further fragmentation was detected after a longer period of treatment, causing a decrease in QQPFP and PQPQLPY, leaving 1.43\% and 15.03\% at $30 \mathrm{~min}$, and $0.16 \%$ and $0.08 \%$ at $60 \mathrm{~min}$, respectively. Moreover, a shorter fragment, P7, was also detected and exhibited a tendency to increase over time (Supplementary Figure S2C). Extract ion chromatograms (EIC) opting for certain fragmentation ions were utilized to certify the intensity changes in P3, P4, and P5, which contained the different stereoisomers (Supplementary Figure S3). 


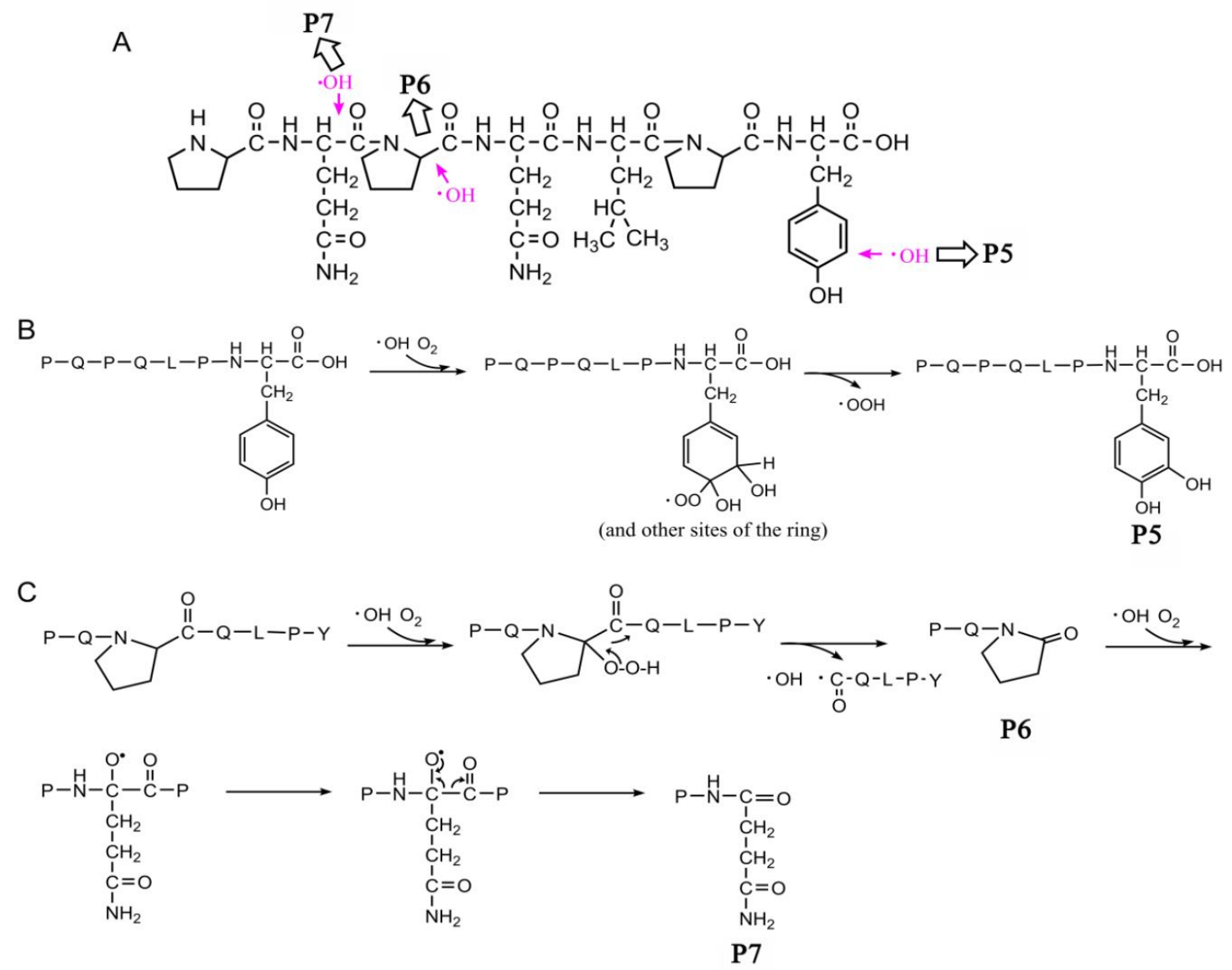

Figure 7. Structures of the celiac-toxic peptide PQPQLPY and its CJAP plasma-modified fragmentation products referred to in this research (P5 P7), which were detected by Orbitrap HR-LC-MS/MS. (A) Structural changes in PQPQLPY during CJAP plasma treatment. The arrow shows the sites attacked in the intermediate region and C-terminus of the specific pentapeptide in this study. (B) P5 was formed through the reaction involving $\bullet \mathrm{OH}$ attack at the benzene ring of Tyr, followed by a reaction with $\mathrm{O}_{2}$ and subsequent elimination of $\bullet \mathrm{OOH}$ to form a mixture of DOPA stereoisomers. (C) The reaction pathway of $\mathrm{P} 6$ and $\mathrm{P} 7$ formation associated with $\bullet \mathrm{OH}$ attack at the Pro residue and the formation of an alkoxy group on the $\alpha$-carbon of Gln.

\subsection{Agglomeration State of Wheat Gliadins Analyzed by SDS-PAGE}

To display size changes in an observable way, gliadin proteins with and without plasma treatment were separated on the 12\% SDS-PAGE. Comparing plasma-treated with untreated samples (Supplementary Figure S4), a decrease in intensity of stripe S1 was observed at the bottom of polyacrylamide gel. Additionally, another visible decrease in intensity of stripes S2 and S3 could also be seen in the plasma-treated samples. These observations demonstrated larger-sized proteins might undergo fragmentation to generate smaller-sized proteins under plasma conditions due to the depolymerization behavior of wheat gliadins during their exposure to the CJAP plasma.

\subsection{Decrease in Quantity of Wheat Gliadins Treated with CJAP Plasma}

To explore the CJAP plasma-treated specific gliadins changes in more detail, the 2-DE gel of gliadin extract is shown in Figure 8, which revealed that some protein spots disappeared or were reduced in quantity with longer CJAP plasma treatment. By comparison with the untreated sample, particular attention was directed toward three protein spots (G1, G2, and G3) with obviously reduced intensity in the treated samples. They were subjected to LC-MS/MS to clarify the type of gliadin. 
To clarify the type of gliadin susceptible to CJAP plasma, those three protein spots arrowed in Figure 8 were subjected to LC-MS/MS experiment for further detection.

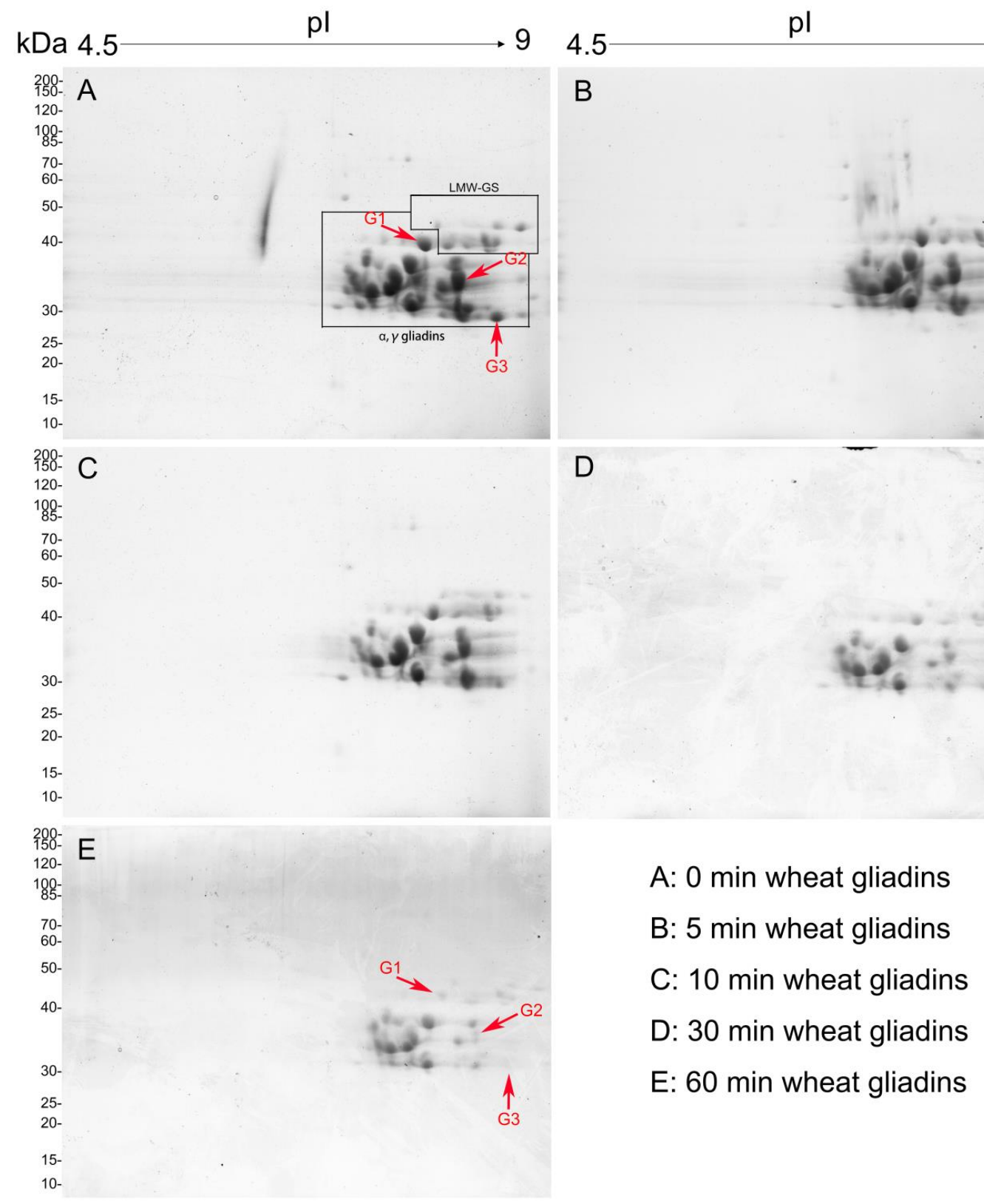

Figure 8. 2-DE detection of protein species in native and CJAP plasma-modified wheat gliadins. The major groups of wheat gliadins are indicated. The molecular weight is indicated on the vertical axis, and isoelectric point is shown on the horizontal axis. The A-E are the wheat gliadin samples treated with CJAP plasma for 0, 5, 10, 30 and $60 \mathrm{~min}$, respectively.

\subsection{LC-MS Identification of Proteins in 2-DE Spots}

Proteins in 2-DE spots indicated by arrows were identified via LC-MS. Table 1 shows that $\gamma$-type gliadins were detected as the predominant protein in those three spots. In these spots, the predominant protein of G1 was a traditional gamma gliadin with an MW of 37,564 Daltons and pI of 8.51. An additional two protein spots (G2 and G3) with an MW of 34,502 and 33,067 Daltons with corresponding $\mathrm{pI}$ of 8.57 and 8.88 were also detected as gamma gliadin. More detailed information regarding these spots is presented in Table 1 below. 
Table 1. LC-MS identification of wheat gliadin spots in 2-DE. The protein name, accession number, mass, pI, protein score, protein match, protein coverage, peptide sequence and mass error (ppm) were presented.

\begin{tabular}{|c|c|c|c|}
\hline Spot & G1 & G2 & G3 \\
\hline Predominant protein & Gamma gliadin & Gamma gliadin & Gamma gliadin \\
\hline Accession number & F2XAR5 & Q30DX7 & K7WVC4 \\
\hline MW & 37,564 & 34,502 & 33,067 \\
\hline pI & 8.51 & 8.57 & 8.88 \\
\hline Protein score & 94 & 1762 & 2831 \\
\hline Protein match & 2 & $91(54)$ & $62(52)$ \\
\hline Protein coverage & - & 25.5 & 15.8 \\
\hline Sequence & $\begin{array}{l}\text { R.APFASIVAGIGGQ. (ppm: 5.18) } \\
\text { R.SLVLQTLPSMCSVYVPPECSIMR.A } \\
\text { (ppm: -44.56) }\end{array}$ & $\begin{array}{l}\text { R.TTTSVPFGVGTGVGAY. (ppm: 8.86) } \\
\text { R.ILPTMCSVNVPLYR.T (ppm: 6.64) } \\
\text { R.ILPTMCSVNVPLYR.T (ppm: 6.85) } \\
\text { K.VFLQQQCSPVAMPQR.L (ppm: 9.19) } \\
\text { R.SQMLQQSSCHVMQQQCCQQLPQ } \\
\text { IPQQSR.Y (ppm: 8.80) }\end{array}$ & $\begin{array}{l}\text { R.SDCQVMQQQCCQQLAQIPR.Q } \\
\text { (ppm: 6.96) } \\
\text { R.SDCQVMQQQCCQQLAQIPR.Q } \\
\text { (ppm: 0.35) } \\
\text { R.QPQQPFYQQPQQTFPQPQQ } \\
\text { AFPHQPK.Q (ppm: 5.81) }\end{array}$ \\
\hline
\end{tabular}

The UniProt database was utilized to the spectral datasets searching.

\subsection{Increment of Carbonyl Groups in Plasma-Treated Wheat Gliadins}

Carbonyl groups are frequently used as biomarkers to demonstrate the protein oxidation level in biological samples [24]. As shown in Figure 9A, the separation gel presented new aggregates resulting from CJAP plasma-induced oxidation of wheat gliadins. Although carbonyl groups were formed in both plasma-treated and untreated samples, dissimilar blot intensities were observed in the samples, with the strongest intensity apparent at 30 and $60 \mathrm{~min}$ (Figure 9B). The quantification results (Figure 9C) revealed an increase in carbonyl groups with plasma treatment from $32.36 \mathrm{nmol} / \mathrm{mL}$ at $5 \mathrm{~min}$ to $86.30 \mathrm{nmol} / \mathrm{mL}$ at $60 \mathrm{~min}$, with a significant increase $(p<0.05)$ first appearing at $10 \mathrm{~min}$ and a highly significant increase $(p<0.01)$ at $60 \mathrm{~min}$ compared with the untreated sample. These results showed that the CJAP plasma-treated wheat gliadins formed more carbonyl groups.
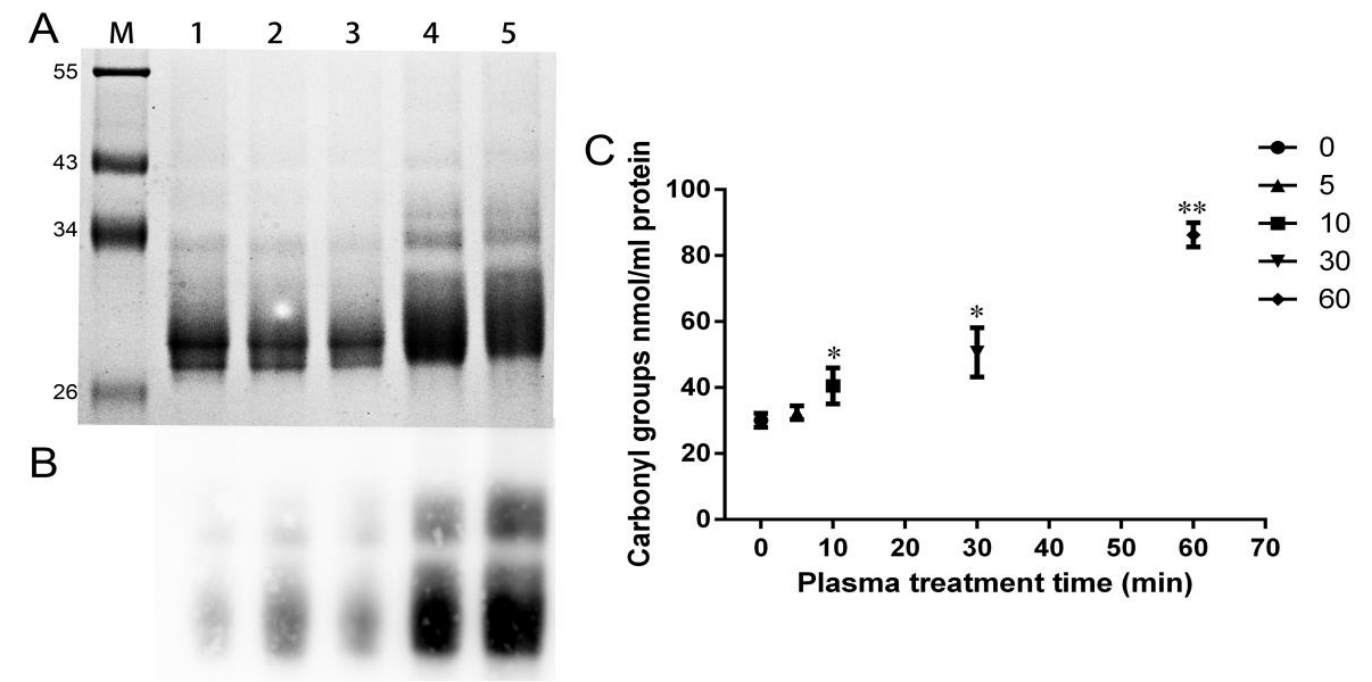

Figure 9. Qualitative and quantitative analysis of carbonyl groups of the wheat gliadin samples treated with CJAP plasma for $0 \mathrm{~min}, 5 \mathrm{~min}, 10 \mathrm{~min}, 30 \mathrm{~min}$ and $60 \mathrm{~min}$, respectively. (A) SDS-PAGE gel stained with CBB. M: Protein molar mass standard, lane 1: $0 \mathrm{~min}$, lane 2: $5 \mathrm{~min}$, lane 3: $10 \mathrm{~min}$, lane 4: $30 \mathrm{~min}$, lane 5: $60 \mathrm{~min}$. (B) Western blot of carbonyl groups using biotin-hydrazide. (C) Quantification of carbonyl groups using the 4-dinitrophenyl-hydrazine (DNPH) method. Data are presented as means \pm $\mathrm{SE}(n=3)$ in the quantitative detection assays. Asterisks represent statistically significant differences from $0 \min \left({ }^{*} p<0.05,{ }^{* *} p<0.01\right)$. 


\subsection{Immunological Activity Evaluation of Wheat Gliadins in ELISA}

The R5 antibody can specifically recognize the epitope QQPFP, which exists in nearly all parts of gliadins [5]. The immunological activities of CJAP plasma-treated wheat gliadins were determined by ELISA. As shown in Figure 10, R5 antibody immunoreactivity in all treated samples exposed for different durations of plasma treatment were lower than in the untreated sample. After 5 min of plasma treatment, the prolamin concentration declined to $86.12 \%$ of its original level, and thereafter $84.23 \%$ of its initial content remained after $10 \mathrm{~min}$ of treatment. The lowest remaining prolamin concentration, at $48.05 \%$ of its initial level, was detected in samples treated with plasma for $60 \mathrm{~min}$ $(p<0.05)$. The decline in prolamin content implied that the epitopes for R5 recognition were modified by plasma treatment, which caused a reduction of immunological activity of wheat gliadins in vitro.

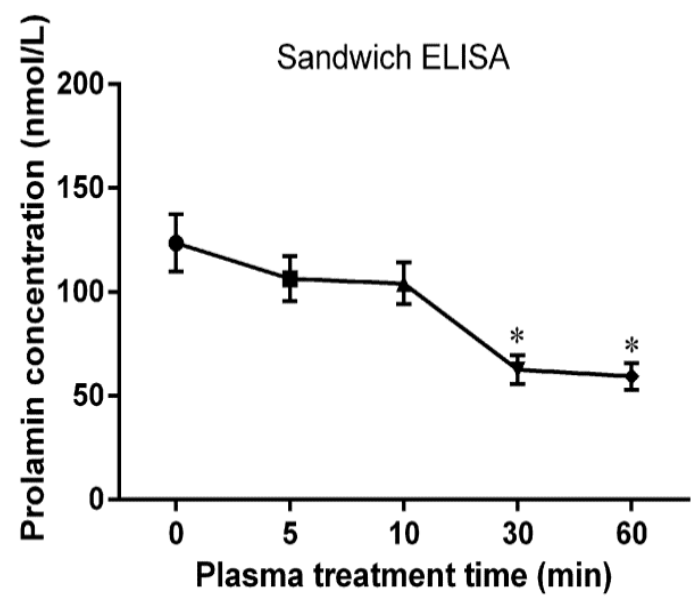

Figure 10. Sandwich ELISA of native and CJAP plasma-modified wheat gliadins. Data are presented as means \pm SE $(n=3)$ in the ELISA system. Asterisks represent statistically significant differences from $0 \min \left({ }^{*} p<0.05\right)$.

\subsection{Size Distribution Change Analysis of Gluten Proteins before and after CJAP Plasma Treatment}

SE-HPLC was a brilliant method for comparison of the molecular size distribution of native and plasma-treated gluten proteins by quantisation of the elution profiles and the size fractionation of those proteins with plasma treatment gave a good intimation of the degree of protein oxidation and modification. In the presence of RONS generated by CJAP plasma, an explicit decline of the peak height of SE-HPLC profiles was observed in the treated samples compared with untreated sample (Figure 11A). As shown in Figure 11B, lower values of F1\% were observed at 5 min and 10 min compared with the untreated sample, with the biggest decrease observed at $60 \mathrm{~min}(p<0.05)$. Besides, the ratios of $\mathrm{F} 1 \% / \mathrm{F} 2 \%$ of CJAP plasma-treated samples gradually decreased and the most significant decline was achieved at $60 \mathrm{~min}(p<0.01)$. The sample treated for $30 \mathrm{~min}$ had significantly higher ratios of $(\mathrm{F} 3 \%+\mathrm{F} 4 \%) / \mathrm{F} 1 \%$ and a further increase appeared at $60 \mathrm{~min}(p<0.05)$. These results implied that there was a time-dependent decrease in the amounts of large-sized polymers in plasma-treated samples when compared to the untreated one, suggesting that depolymerization of macropolymers probably occurred during plasma treatment. 
A

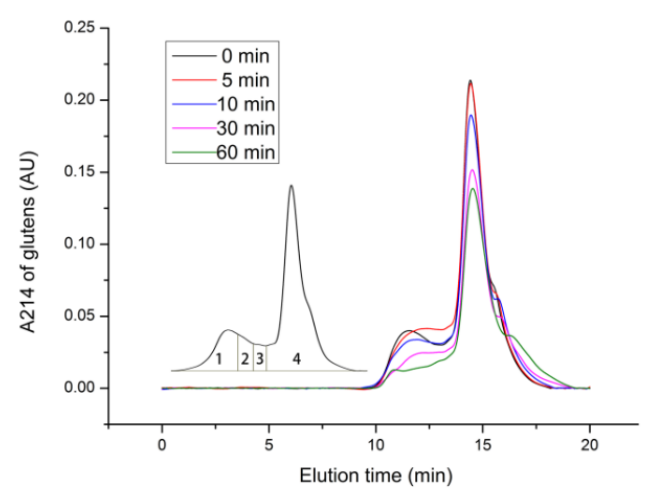

B

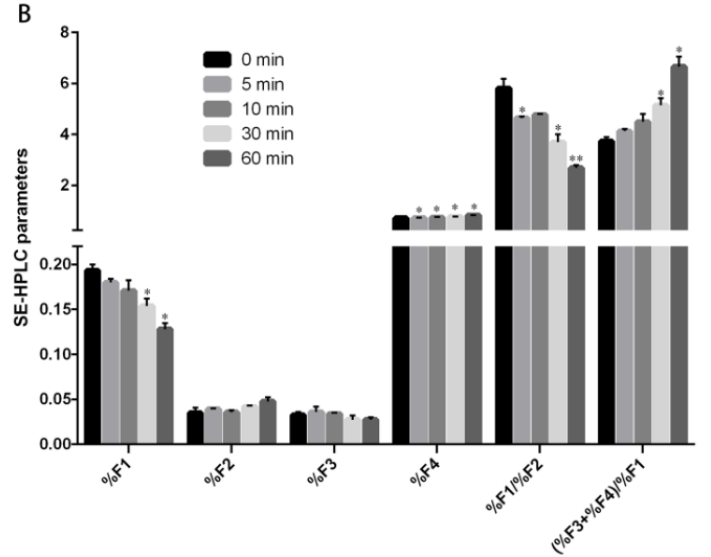

Figure 11. The influence of CJAP plasma on the aggregate formation of wheat gluten proteins. (A) SE-HPLC chromatogram curve of native and CJAP plasma-modified wheat gluten proteins. The inset refers to the area division of the wheat storage protein distribution, which corresponded to large-sized polymers (F1), medium-sized polymers (F2), monomeric and oligomeric proteins (F3) and monomeric gliadins and non-gluten proteins (F4). (B) with corresponding comparisons of six parameters $(\% \mathrm{~F} 1, \% \mathrm{~F} 2, \% \mathrm{~F} 3, \% \mathrm{~F} 4, \% \mathrm{~F} 1 / \% \mathrm{~F} 2$, and $(\% \mathrm{~F} 3+\% \mathrm{~F} 4) / \% \mathrm{~F} 1)$ analyzed statistically. Data are presented as means $\pm \mathrm{SE}(n=3)$ in the assays. Asterisks represent statistically significant differences from $0 \min \left(* p<0.05,{ }^{* *} p<0.01\right)$.

\section{Discussion}

In this context, an assortment of reactive oxygen and nitrogen species such as $\mathrm{O}_{3}, \bullet \mathrm{OH}, \mathrm{H}_{2} \mathrm{O}_{2}$, $\mathrm{NO}_{2}{ }^{-}$, and $\mathrm{NO}_{3}{ }^{-}$generated during plasma treatment entailed that samples were subjected to an environment with high possibility of oxidation and modification. Moreover, the immunoreactivity of gliadin in wheat was successfully attenuated via CJAP-plasma modification, with oxidation and hydroxylation being of the major importance. Meanwhile, an Orbitrap HR-LC-MS/MS method was utilized to demonstrate the degree of oxidation at specific Pro and Gln and hydroxylation at Phe and Tyr through analyzing the products originated from plasma-treated peptides, QQPFP, and PQPQLPY.

\subsection{CJAP Plasma can Generate a Variety of RONS}

A diversity of RONS such as $\mathrm{O}_{3}, \bullet \mathrm{OH}, \mathrm{H}_{2} \mathrm{O}_{2}, \mathrm{NO}_{2}{ }^{-}$and $\mathrm{NO}_{3}{ }^{-}$generated during CJAP-plasma treatment, indicating samples were subjected to an environment with a high possibility of oxidation and hydroxylation modification. RONS is in a dynamic process of mutual transformation. The $\mathrm{OH}$ radicals were found to be of great significance for oxidation and hydroxylation reactions. There are mainly two kinds of reaction pathways leading to the generation of $\mathrm{OH}$ radicals, which may explain the gradual increase of $\bullet \mathrm{OH}$ density during CJAP-plasma treatment $[25,26]$. One is the dissociation of radicals and metastables (Reactions 1 and 2), and the other is the electron dissociation of $\mathrm{H}_{2} \mathrm{O}$ (Reaction 3). Furthermore, it is well-documented that $\mathrm{O}_{3}$ can preferentially produce in DBD, and $\mathrm{O}_{3}$ mainly emerged from the reaction (Reaction 4 ) between the dissolved atomic oxygen and molecular oxygen $[27,28]$.

$$
\begin{gathered}
\mathrm{e}+\mathrm{O}_{2} \rightarrow \mathrm{O}\left({ }^{3} \mathrm{P}\right)+\mathrm{O}\left({ }^{1} \mathrm{D}\right) \\
\mathrm{O}\left({ }^{1} \mathrm{D}\right)+\mathrm{H}_{2} \mathrm{O} \rightarrow 2 \mathrm{OH} \\
\mathrm{e}^{-}+\mathrm{H}_{2} \mathrm{O} \rightarrow \mathrm{OH}+\mathrm{H}+\mathrm{e}^{-} \\
\mathrm{O}+\mathrm{O}_{2} \leftrightarrow \mathrm{O}_{3}
\end{gathered}
$$

According to Liu et al. (2016), the interaction (Reaction 5) between $\mathrm{HO}_{2}$ and $\mathrm{HO}_{3}$ is responsible for $\mathrm{H}_{2} \mathrm{O}_{2}$ generation [28]. It is worth mentioning that highly reactive $\mathrm{OH}$ radicals with a high density within 
a small diffusion length should be balanced via the recombination reaction (Reaction 6), which also contributes to the increase in $\mathrm{H}_{2} \mathrm{O}_{2}$.

$$
\begin{gathered}
\mathrm{HO}_{2}+\mathrm{HO}_{3} \rightarrow \mathrm{H}_{2} \mathrm{O}_{2}+\mathrm{O}_{2} \\
\mathrm{OH}+\mathrm{OH} \rightarrow \mathrm{H}_{2} \mathrm{O}_{2}
\end{gathered}
$$

During the course of plasma treatment, various nitrogen oxides such as $\mathrm{NO}, \mathrm{NO}_{2}{ }^{-}$and $\mathrm{NO}_{3}{ }^{-}$ were detected, which presumably accounted for the decrease in $\mathrm{pH}$ value and increase in the density of $\mathrm{NO}_{2}{ }^{-}$and $\mathrm{NO}_{3}{ }^{-}$in our experiment [29].

\subsection{CJAP Plasma-Induced Oxidation and Hydroxylation at Specific Pro, Gln, Phe, and Tyr Residues Lead to} Reduction and Modification of Celiac-Toxic Peptides

Considering that the principal toxic components were not randomly scattered but clustered in Pro- and Gln-rich regions of gliadin, the modification and degradation of celiac-toxic peptides with application of CJAP plasma became our principle objective. Free radicals are available to attack substrates in various media, and the $\bullet \mathrm{OH}$ accessibility of Pro, Gln, Phe and Tyr residues is critical for the formation of oxidation and hydroxylation products under CJAP plasma conditions. The higher Pro content in peptide PQPQLPY than in peptide QQPFP resulted in larger amounts of 2-pyrolidone products under RONS attack. A larger number of hydroxylation products was found in PQPQLPY than in QQPFP (Supplementary Figure S2). This finding may be attributed to the location of Tyr residue at the C-terminus of PQPQLPY, which was more attractive for $\mathrm{OH}$ radical attack [30]. Besides, the hydroxyl group in the benzene ring of Tyr residue could also increase reactivity of ortho-/meta-carbon compared with that of Phe residue.

The peak area of P1 P7 first appeared to increase, possibly owing to bond cleavage in peptide side chain, which was due to the addition of an oxygen atom to alpha carbon to generate a carbonyl and the introduction of a hydroxyl group resulting from the addition reaction on an aromatic ring of Phe [31,32]. Importantly, the P1, P2 and P6 detected by LC-MS/MS indicated that $\bullet \mathrm{OH}$-mediated cleavage of the peptide played an important role in attack of Pro residue at the C-terminus of specific pentapeptide and heptapeptide in 2-pyrrolidone formation in the presence of $\mathrm{O}_{2}$ [33]. For P3 and $\mathrm{P} 4, \bullet \mathrm{OH}$ rapidly attacked the benzene ring of Phe to generate a hydroxyl cyclohexadienyl radical, followed by a reaction with $\mathrm{O}_{2}$ and subsequent elimination of $\bullet \mathrm{OOH}$ to form $o-/ m-/ p$-Tyr (P3) and DOPA stereoisomers (P4). The substituent containing an unshared electron pair on the benzene ring can form a $p$ - $\pi$-conjugated system with the benzene ring, resulting in an increase in the electron cloud density of the benzene ring, especially at ortho and para positions, which favors attack of the electrophilic group $\bullet \mathrm{OH}$ generated by the plasma treatment process to form a mixture of $o-/ m-/ p$-Tyr (P3), which was responsible for three peaks in extract ion chromatograms as shown in Supplementary Figure S3A [34]. Attack of the second hydroxyl group has more positional selectivity due to the strong guiding action of the first hydroxyl substituent, leading to generation of the DOPA products (P4) [21].

Backbone cleavage mediated by the highly accumulated $\mathrm{OH}$ radical population induced by CJAP-plasma appears to occur at multiple sites, with positions adjacent to Pro residues at the C-terminus being of major importance [35]. With an open structure and water-soluble properties, two model peptides show greater availability for attack by $\mathrm{OH}$ radicals. Encouragingly, plasma treatment of peptides was more efficient in terms of structural changes of peptide than Fe/EDTA/AA treatment of QQPFP, for which $22 \%$ of the original peptide remained intact after $24 \mathrm{~h}$ of oxidation [5]. In contrast, $0.16 \%$ of peptide remained after $60 \mathrm{~min}$ of plasma processing in our experiment.

\subsection{Decreased Immunoreactivity of Wheat Gliadins Modified by the CJAP Plasma}

The chief epitope for R5 antibody binding is specific pentapeptide (QQPFP) in gliadins. Modification of the FP motif was a key factor in reducing the immunoreactivity of gliadin in R5-antibody recognition [30]. The Pro and ring structure of Phe can be oxidized more readily by $\mathrm{OH}$ 
radicals generated by CJAP plasma in our work. Numerous Pro and Gln are present in the primary structure of gliadin, and smaller fragments of gliadins could be produced at the $\alpha$-carbon side of Pro and Gln when it was attacked by the RONS induced by CJAP plasma, making it easier for $\mathrm{OH}$ radicals to approach the exposed Pro sites of gliadins. Considering the fragmentation and side-chain modifications of the gliadin epitopes, a decreased ability of R 5 antibody for detection of its binding sites was achieved in vitro. The $48.05 \%$ of original immunoreactivity against the R5 antibody was retained in gliadin treated with plasma for $60 \mathrm{~min}$, compared with approximately $60 \%$ following 2-h metal-catalyzed oxidation of hordein [5]. The CJAP plasma could bring about the backbone cleavage and degradation of gluten protein (Figure 11), which resulted in the exposure of more epitope for $\bullet \mathrm{OH}$. Besides, it could produce the higher density of $\mathrm{OH}$ radicals at high voltage. These both contribute to the more decreased immunoreactivity than that of metal catalysis.

It is worth mentioning that although we have proved that CJAP plasma can reduce the immune activity of gliadin in vitro, more studies need to be done to verify the effectiveness of cold plasma technology. The gluten-specific $\mathrm{CD} 4^{+} \mathrm{T}$-cells could be activated inappropriately, triggered by gluten peptides bound to DQ2 and DQ8 heterodimers in vivo [4]. To date, 24 celiac disease-related epitopes have been identified from wheat gluten that induced T-cell response in patients with celiac disease [36]. Hence, it is important that using specific T-cell clones to evaluate celiac immunological activity [37]. Furthermore, it is reported that epitopes rich in Glu and Pro are derived from gluten across all different classes and the celiac disease is triggered by very small amounts of gluten [38]. Therefore, optimization of the discharge parameters of cold plasma is necessary to improve the efficiency of decreasing the immune activity. The development of stronger energy plasma could encourage to eliminate the celiac sensitivity of gluten in the future. Regarding that gluten is embed in complex matrix of lipids, starch and proteins, the region exposed to the digestive enzymes is closely related to those matrices. This accounts for the problematic quantification and identification of digestible peptides, which is significant for the gluten epitopes related to celiac disease [39]. Plasma modification target should be extended to the complex and diverse foods in the practical application.

\subsection{Decrease in Large-Sized Polymers through Longer Exposure to CJAP Plasma}

The agglomeration state with reduction of large-sized proteins and the appearance of small-sized proteins were observed by SDS-PAGE and SE-HPLC. We attributed the increase of small-sized aggregates to bond cleavage at Pro and Gln of the original protein due to the oxidation of RONS generated by CJAP plasma [40]. Based on the LC-MS results, it was found that plasma modification could cause quantitative decrease in gliadin with selectivity for $\gamma$-gliadin, and the longer plasma treatment, the greater was degree of protein reduction (Figure 8). The N-terminus comprising mostly highly repetitive sequences rich in Pro and Gln is distinct for each type of gliadin. For $\gamma$-gliadin, the typical unit, QPQQPFP, is repeated up to 16 times, which is more than that of the other gliadins [41]. $\gamma$-gliadin contained lower single-bond energy amino acid residues and its arrangement was less regular and less compact than that of $\alpha / \beta$ gliadin, which could also facilitate its attack by RONS [30,42].

\subsection{Proposed Mechanism of the Model Peptide and Wheat Storage Protein Modified by CJAP Plasma}

Based on the analytical results described above, possible mechanisms of two model peptide and wheat storage protein modified by CJAP plasma are shown in Figure 12. By performing cold jet plasma treatment under atmospheric pressure, large quantities of RONS could be produced. These RONS could cause the depolymerization of gluten protein and quickly attacked specific Pro and Gln residues to give rise to the 2-pyrolidone (P1, P2 and P6) and alkoxylate products (P7), respectively. In addition, aromatic amino acids such as Phe and Tyr were hydroxylated, and monohydroxylated Phe (P3), DOPA (P4) and monohydroxylated Tyr (P5) products are formed in the presence of RONS. Amino acid modifications and peptide cleavage, incorporated with gluten protein fragments induced by plasma treatment, generated a variety of smaller-sized aggregates and reduced the immunoreactivity of wheat storage protein. 


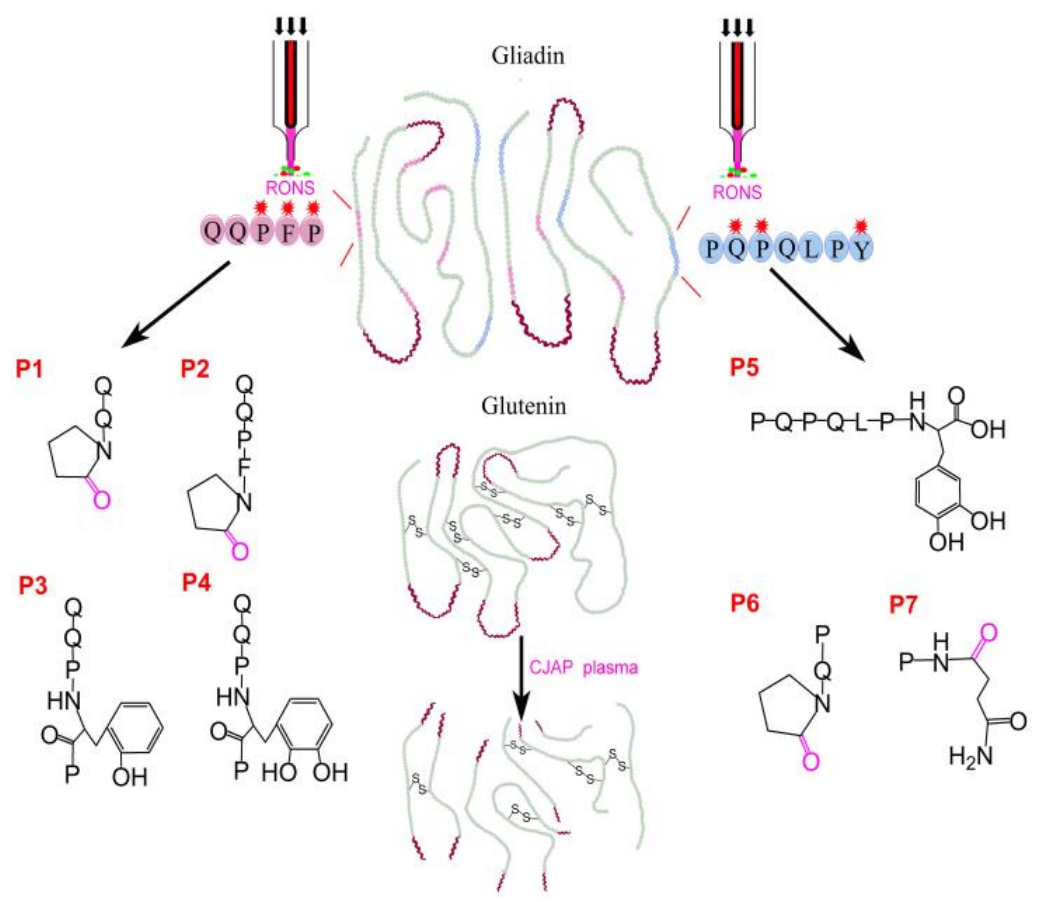

Figure 12. Schematic mechanism for wheat storage proteins and model celiac-toxic peptides modified by CJAP plasma.

\section{Materials and Methods}

\subsection{Materials}

The celiac-toxic peptides QQPFP (molecular weight, MW $=615.68 \mathrm{~g} / \mathrm{mol}$, purity $85.1 \%$ ) and PQPQLPY (MW $=841.95 \mathrm{~g} / \mathrm{mol}$, purity $89.5 \%$ ) were synthesized by Bioyeargene Biotechnology Inc. (Wuhan, China). The gliadins and storage proteins in wheat were extracted from flour of Zhengmai 9023 (Triticum aestivum L.), which was planted in the experimental field at Huazhong University of Science and Technology (HUST) (Wuhan, China).

\subsection{Discharge, Current and Optical Emission Spectra (OES) Detection}

Set voltage and discharge current were simultaneously measured by a Tektronix MSO 3045 mixed signal oscilloscope with a Tektronix P6015A high-voltage (H.V.) probe and a Pearson current monitor (Pearson Electronics, Palo Alto, CA, USA).

\subsection{Extraction of Gliadins from Wheat}

The gliadins in wheat were extracted as described by Marsh (2000) [42]. A fraction of $100 \mathrm{~g}$ flour was added to $1 \mathrm{~L}$ of water-saturated butanol solution and stirred constantly for $1 \mathrm{~h}$ at $20^{\circ} \mathrm{C}$ After centrifugation $\left(5000 \times g, 10 \mathrm{~min}, 20^{\circ} \mathrm{C}\right)$ the precipitate was mixed with $1 \mathrm{~L}$ of $0.5 \mathrm{M} \mathrm{NaCl}$ for $1 \mathrm{~h}$ at $20^{\circ} \mathrm{C}$. This step was repeated twice. Next, pellet was washed with $1 \mathrm{~L}$ of distilled water for $10 \mathrm{~min}$ and centrifuged $\left(5000 \times \mathrm{g}, 10 \mathrm{~min}, 20^{\circ} \mathrm{C}\right)$ again. The precipitate was dissolved in $1 \mathrm{~L}$ of $70 \%$ ethanol $(v / v)$ for $1 \mathrm{~h}$ at $20^{\circ} \mathrm{C}$ and centrifuged at $50,000 \times \mathrm{g}$ in $20^{\circ} \mathrm{C}$ for $10 \mathrm{~min}$ to collect supernatant. The supernatant containing gliadins was obtained during this procedure.

\section{4. $\mathrm{O}_{3}$ Measurement}

The content of $\mathrm{O}_{3}$ was detected using N,N-diethyl-p-phenyl-enediamine (DPD) method. A commercial kit (HuanKai Biotechnology, Guangzhou, China) was used in this experiment. Treated samples were supplemented with DPD reagent, which could react with $\mathrm{O}_{3}$ to induce a color change of solution. The color depth of solution is positively correlated with amount of $\mathrm{O}_{3}$. 


\section{5. $\mathrm{H}_{2} \mathrm{O}_{2}$ and $\mathrm{pH}$ Measurement}

The concentration of $\mathrm{H}_{2} \mathrm{O}_{2}$ was measured using a Hydrogen Peroxide assay kit (Beyotime, Shanghai, China). The testing solution was mixed with sample at a ratio of 1:1 (v/v). $200 \mu \mathrm{L}$ of mixed solution was allowed to remain at room temperature for $30 \mathrm{~min}$ and measured at a wavelength of $570 \mathrm{~nm}$ using microplate reader. $\mathrm{pH}$ test strips were used to measure the $\mathrm{pH}$ value.

\section{6. $\bullet \mathrm{OH}$ Measurement}

The terephthalic acid (TA) method was employed for determination of hydrogen groups. TA was dissolved in $1.4 \mathrm{mM} \mathrm{NaOH}$ solution to obtain a $0.2 \mathrm{mM}$ TA solution. The fluorescence microplate reader (FlexStation3, Molecular Devices, San Francisco, CA, USA) was used to measure the absorbance value of hydroxyl group at an excitation wavelength of $310 \mathrm{~nm}$ and an emission wavelength of $425 \mathrm{~nm}$.

\subsection{Total Content of $\mathrm{NO}_{2}{ }^{-}$and $\mathrm{NO}_{3}{ }^{-}$Determination}

The total concentrations of $\mathrm{NO}_{2}{ }^{-}$and $\mathrm{NO}_{3}{ }^{-}$were analyzed with Nitric Oxide (NO) assay kit (Nitrate reductase method, Nanjing Jiancheng Bioengineering Institute, Nanjing, China). The reaction between $\mathrm{NO}_{3}{ }^{-}$and nitrate reductase leads to the formation of $\mathrm{NO}_{2}{ }^{-}$.

\subsection{Identification of CJAP Plasma Treatment Fragments by Orbitrap HR-LC-MS/MS}

The Q. Exactive Orbitrap HR-LC-MS/MS was applied to analyze the obtained CJAP plasma treatment peptide mixtures. An Ultimate 3000 UPLC system equipped with an Accucore aQ column $(2.1 \times 150 \mathrm{~mm}, 2.6 \mu \mathrm{m}$ Thermo Scientific, Waltham, MA, USA) was coupled to the quadrupole electrostatic field orbital trap mass spectrometer (Q Exactive, Thermo Scientific, Waltham, MA, USA) in positive mode. The ESI pattern was used as ion source with a scanning range from 50 to $2400 \mathrm{~m} / \mathrm{z}$. Solvent A and solvent B consisted of an aqueous solution of $0.1 \%$ formic acid in water and of $0.1 \%$ formic acid in acetonitrile, respectively. A gradient of acetonitrile from $99 \%$ solvent A to $99 \%$ solvent $\mathrm{B}$ was generated for $20 \mathrm{~min}$ at a flow rate of $0.2 \mathrm{~mL} / \mathrm{min}$. The Xcalibur software (Thermo Scientific, Waltham, MA, USA) was applied for analysis of MS result.

\subsection{Quantitative 2-DE and LC-MS Analysis}

The CJAP plasma-treated wheat gliadins were separated by 2-DE as described by Nagib et al. (2010) [43]. First, $200 \mu \mathrm{L}$ of the gliadin sample $(1.25 \mu \mathrm{g} / \mu \mathrm{L})$ was mixed with hydration loading buffer containing $8 \mathrm{M}$ urea, $0.2 \%$ Bio-Lyte $(w / v), 4 \%$ CHAPS (w/v) and $65 \mathrm{mM}$ dithiothreitol (DTT). Each sample was subjected to IPG prefabricated strips pH 3-10 (7 cm, ReadyStrip, Bio-Rad, Irvine, CA, USA) with $16 \mathrm{~h}$ rehydration. IEF was applied using a PROTEAN IEF Cell (Bio-Rad, Irvine, CA, USA) at $17^{\circ} \mathrm{C}$ with a series of voltages: $250 \mathrm{~V}$ and $500 \mathrm{~V}$ for desalting, 500-4000 V linear boost and $4000 \mathrm{~V}$ for focus. After IEF, IPG prefabricated strips were equilibrated in an equilibration buffer containing $6 \mathrm{M}$ urea, $2 \%$ SDS $(w / v), 0.375 \mathrm{M}$ Tris- $\mathrm{HCl}(\mathrm{pH} 8.8)$ and 20\% (v/v) glycerol including 2\% (w/v) DTT for $15 \mathrm{~min}$, followed by a strip equilibration buffer containing $2.5 \%$ iodoacetamide $(w / v)$ for another $15 \mathrm{~min}$. In the second dimension, SDS-PAGE of a 12\% separation gel at $20 \mathrm{~mA}$ was applied until blue dye line reached the end of gel.

Three sets of selected protein spots from 2-D gels were excised for trypsin digestion $\left(37^{\circ} \mathrm{C}, 16 \mathrm{~h}\right)$, according to the literature reported by Martinez-Esteso et al. (2016) [44]. The obtained peptide samples from digested protein spots were dissolved ( $0.1 \%$ formic acid, 5\% acetonitrile) and loaded into the $Q$ Exactive mass spectrometer equipped with a $75 \mu \mathrm{m}$ i.d. $\times 150 \mathrm{~mm}$, packed with an Acclaim PepMap RSLC C18, $2 \mu \mathrm{m}, 100 \AA$, nanoViper column for sequence identification (Thermo Scientific, Waltham, MA, USA). Solvent A and solvent B consisted of an aqueous solution of $0.1 \%$ formic acid in water and of $0.1 \%$ formic acid, $80 \% \mathrm{ACN}$, respectively. The MS original file was processed and converted using MM File Conversion software to obtain the MGF format file, and the NCBI database and UniProt sapiens database were retrieved using MASCOT. 


\subsection{Qualitative and Quantitative Detection of Carbonyl Groups}

The content of carbonyl groups was measured by 2,4-dinitrophenyl -hydrazine (DNPH) method [24]. First, 50- $\mu \mathrm{L}$ gliadin sample was supplemented with $800 \mu \mathrm{L}$ of $10 \mathrm{mM}$ DNPH in $2.5 \mathrm{M}$ $\mathrm{HCl}$, with $2.5 \mathrm{M} \mathrm{HCl}$ as a control. Two tubes were placed at room temperature for $1 \mathrm{~h}$. The samples were precipitated with $1 \mathrm{~mL}$ of $20 \%$ trichloroacetic acid (TCA) $(w / v)$ and left in an ice box for $5 \mathrm{~min}$. After centrifugation $\left(10,000 \times \mathrm{g}, 10 \mathrm{~min}, 4^{\circ} \mathrm{C}\right)$, the precipitate was washed with $1 \mathrm{~mL}$ of $10 \% \mathrm{TCA}$ and centrifuged $\left(10,000 \times g, 10 \mathrm{~min}, 4^{\circ} \mathrm{C}\right)$. The precipitates were washed three times with $1 \mathrm{~mL}$ ethanol-ethyl acetate $(1: 1, v / v)$. The obtained pellets were dissolved in $500 \mu \mathrm{L}$ of $6 \mathrm{M}$ guaninide hydrochloride with general vortexing and again centrifuged $\left(10,000 \times g, 10 \mathrm{~min}, 4^{\circ} \mathrm{C}\right)$. Finally, $220 \mu \mathrm{L}$ of supernatant from each tube was collected and the carbonyl content was calculated based on the absorption at $375 \mathrm{~nm}$.

\subsection{Sandwich Enzyme-Linked Immunosorbent Assay (ELISA)}

A commercial ELISA kit (Gliadin, ml058393-2, Shanghai Enzyme-linked Biotechnology Co. Ltd., Shanghai, China) was applied to measure the concentration of prolamin. In the first step, $10 \mu \mathrm{L}$ of CJAP-treated and untreated samples were added to $40 \mu \mathrm{L}$ of sample diluent. All samples were then incubated at $37^{\circ} \mathrm{C}$ for $30 \mathrm{~min}$. The samples were washed five times with a washing solution. The samples were mixed with $50 \mu \mathrm{L}$ of HRP-Conjugate reagent, incubated again at $37^{\circ} \mathrm{C}$ for $30 \mathrm{~min}$ and then incubated and washed as described above. Thereafter, $50 \mu \mathrm{L}$ each of reagent $\mathrm{A}$ and reagent $\mathrm{B}$ were mixed in the dark at $37^{\circ} \mathrm{C}$ for $10 \mathrm{~min}$. Finally, $50 \mu \mathrm{L}$ of stop solution was used to terminate reaction. The concentration of prolamin can be calculated by absorption curve measured at a wavelength of $450 \mathrm{~nm}$. Samples without addition of HRP-Conjugate reagents served as a blank control.

\subsection{SE-HPLC Analysis}

The gluten proteins were collected with $50 \mathrm{mM}$ of sodium phosphate buffer with $0.5 \%$ SDS $(w / v$, $\mathrm{pH}$ 6.9) from flour of Zhengmai 9023 (T. aestivum L.), based on the documentation reported by Li et al. (2017) [45]. A 20- $\mu \mathrm{L}$ portion of supernatant filtered from a nylon membrane (pore size $0.45 \mu \mathrm{m}$ ) was poured into a Waters 1525 binary HPLC pump, fractionated on a Phenomenex Biosep-SEC-s4000 column (20 $\left.\mathrm{min}, 0.5 \mathrm{~mL} \mathrm{~min}^{-1}\right)$ and then further tested at $214 \mathrm{~nm}$ using a Waters 2998 photodiode array detector (Waters Corp., Milford, CT, USA).

\subsection{Statistical Analysis}

The statistical software GraphPad Prism 6.0 (Microsoft Corporation, Redmond, WA, USA) was used for statistical analysis via one-way analysis of variance (ANOVA) followed by Tukey mean-comparison procedure. The $5 \%$ significant differences $(p<0.05)$ and $1 \%$ highly significant differences $(p<0.01)$ were evaluated using Origin 8.1 (OriginLab Corporation, Northampton, MA, USA).

\section{Conclusions}

In conclusions, fragmentation at Pro residues, along with modifications at Phe and Tyr residues of two CD-related peptides-QQPFP and PQPQLPY_could be achieved with the application of CAJP plasma. A variety of RONS such as $\mathrm{OH}, \mathrm{O}_{3}, \mathrm{H}_{2} \mathrm{O}_{2}, \mathrm{NO}_{2}{ }^{-}$, and $\mathrm{NO}_{3}{ }^{-}$were observed to increase during plasma processing. In addition, the immunoreactivity of gliadin using the R5 antibody appeared to be reduced because a large amount of recognition epitopes were modified after plasma treatment. Furthermore, the longer the plasma treatment, the greater was the formation of carbonyl and hydroxylation products and, consequently, the smaller was the size of the formed aggregates. The structural changes in the two model peptides, as well as the quantitative changes in gliadin after plasma treatment, favored the preparation of gluten-related product for the celiac disease patients. 
Supplementary Materials: Supplementary materials can be found at http://www.mdpi.com/1422-0067/21/3/1012/ s1. Figure S1. HR-LC chromatogram analysis of CJAP plasma-modified QQPFP and PQPQLPY identified by Orbitrap HR-LC-MS/MS at treatment times of $0 \mathrm{~min}, 5 \mathrm{~min}, 10 \mathrm{~min}, 30 \mathrm{~min}$ and $60 \mathrm{~min}$, respectively. (A) QQPFP, (B) PQPQLPY. The black arrow indicates CJAP plasma-modified products of two celiac-toxic peptides. Figure S2. Two model peptides QQPFP and PQPQLPY modified by CJAP plasma. (A) The changes in the HR-LC-MS/MS peak area of QQPFP and PQPQLPY with the different treatment time. (B) The changes in HR-LC-MS/MS peak area of products P1 P4 from QQPFP with the different treatment time. (C) The changes in HR-LC-MS/MS peak area of products P5 P7 from PQPQLPY with different treatment time. Figure S3. Extract ion chromatograms (EIC) selected for certain fragmentation ions were utilized to certify the intensity changes of P3 (A), P4 (B) and P5 (C). Figure S4. SDS-PAGE analysis of the gliadins in wheat with different CJAP plasma treatment times. M: Protein molar mass standard, lane 1: $0 \mathrm{~min}$ treatment, lane 2: $5 \mathrm{~min}$ treatment, lane 3: $10 \mathrm{~min}$ treatment, lane 4: $30 \mathrm{~min}$ treatment and lane 5: 60 min treatment.

Author Contributions: G.H., G.Y. and F.S. conceived and designed the study. F.S., X.X. and Y.Z. performed all the biological experiments and analyzed the data. F.S., J.D., and M.M. participated in the physics experiments. Y.W. provided some help in the SE-HPLC experiment and its data analysis. D.Q. and X.L. proposed some valuable suggestions to the study. F.S. and X.X. wrote the draft manuscript. G.H. and G.Y. revised and finalized the manuscript. All authors have read and agreed to the published version of the manuscript.

Funding: The work was supported by National Genetically Modified New Varieties of Major Projects of China (2016ZX08010004-004) and the National Natural Science Foundation of China (Nos. 31771418, 31570261), and Key Project of Hubei Province (2017AHB041).

Acknowledgments: The authors acknowledge the Analytical and Testing Center of Huazhong University of Science and Technology (HUST) for technical assistance in the fragments identification of celiac-toxic peptides by used of Orbitrap HR-LC-MS/MS.

Conflicts of Interest: The authors declare that the research was accomplished without any commercial or financial relationships that could be identified as a potential conflict of interest.

\section{Abbreviations}

$\begin{array}{ll}\text { CJAP } & \text { cold jet atmospheric pressure plasma } \\ \text { RONS } & \text { reactive oxygen and nitrogen species } \\ \text { CD } & \text { celiac disease } \\ \text { QQPFP } & \text { Gln-Gln-Pro-Phe-Pro } \\ \text { PQPQLPY } & \text { Pro-Gln-Pro-Gln-Leu-Pro-Tyr } \\ \text { MW } & \text { molecular weight } \\ \text { kDa } & \text { kiloDalton } \\ \text { SDS } & \text { Sodium dodecyl sulfate } \\ \text { DNPH 2 } & \text { 4-dinitrophenyl-hydrazine } \\ \text { EDTA } & \text { ethylenediamine-tetraacetic acid } \\ \text { DTT } & \text { dithiothreitol } \\ \text { AC } & \text { alternating current } \\ \text { OES } & \text { optical emission spectra } \\ \text { H.V. } & \text { high-voltage } \\ \text { DPD } & \text { N,N-diethyl-p-phenyl-enediamine } \\ \text { TA } & \text { terephthalic acid } \\ \text { HR-LC-MS/MS } & \text { high resolution-liquid chromatography-mass spectrometry/mass spectrometry } \\ \text { EIC } & \text { extract ion chromatograms } \\ \text { SDS-PAGE } & \text { sodium dodecyl sulfate-polyacrylamide gel electrophoresis } \\ \text { 2-DE } & \text { two dimensional electrophoresis } \\ \text { IEF } & \text { isoelectric focusing } \\ \text { ELISA } & \text { sandwich enzyme-linked immunosorbent assay } \\ \text { SE-HPLC } & \text { size exclusion high performance liquid phase chromatography } \\ \text { HMW } & \text { high molecular weight; LMW, low-molecular-weight } \\ \end{array}$




\section{References}

1. Shewry, P. Wheat. J. Exp. Bot. 2009, 60, 1537-1553. [CrossRef] [PubMed]

2. Valerii, M.; Ricci, C.; Spisni, E.; Silvestro, R.; Fazio, L.; Cavazza, E.; Lanzini, A.; Campieri, M.; Dalpiaz, A.; Pavan, B. Responses of peripheral blood mononucleated cells from non-celiac gluten sensitive patients to various cereal sources. Food Chem. 2015, 176, 167-174. [CrossRef] [PubMed]

3. Sánchez-León, S.; Gil-Humanes, J.; Ozuna, C.; Giménez, M.; Sousa, C.; Voytas, D.; Barro, F. Low-gluten, non-transgenic wheat engineered with CRISPR/Cas9. Plant Biotechnol. J. 2017, 16, 902-910. [CrossRef] [PubMed]

4. Gianfrani, C.; Siciliano, R.; Facchiano, A.; Camarca, A.; Mazzeo, M.; Costantini, S.; Salvati, V.; Maurano, F.; Mazzarella, G.; Iaquinto, G.; et al. Transamidation of wheat flour inhibits the response to gliadin of intestinal T cells in celiac disease. Gastroenterology 2007, 133, 780-789. [CrossRef] [PubMed]

5. Huang, X.; Sontag-Strohm, T.; Stoddard, F.; Kato, Y. Oxidation of proline decreases immunoreactivity and alters structure of barley prolamin. Food Chem. 2017, 214, 597-605. [CrossRef]

6. Wongsagonsup, R.; Deeyai, P.; Chaiwat, W.; Horrungsiwat, S.; Leejariensuk, K.; Suphantharika, M.; Fuongfuchat, A.; Dangtip, S. Modification of tapioca starch by non-chemical route using jet atmospheric argon plasma. Carbohydr. Polym. 2014, 102, 790-798. [CrossRef]

7. Cuadrado, C.; Cabanillas, B.; Pedrosa, M.M.; Varela, A.; Guillamon, E.; Muzquiz, M.; Crespo, J.; Rodriguez, J.; Burbano, C. Influence of thermal processing on IgE reactivity to lentil and chickpea proteins. Mol. Nutr. Food Res. 2010, 53, 1462-1468. [CrossRef]

8. Sandhu, H.; Manthey, F.; Simsek, S. Ozone gas affects physical and chemical properties of wheat (Triticum aestivum L.) starch. Carbohydr. Polym. 2012, 87, 1261-1268. [CrossRef]

9. Misra, N.; Kaur, S.; Tiwari, B.; Kaur, A.; Singh, N.; Cullen, P. Atmospheric pressure cold plasma (ACP) treatment of wheat flour. Food Hydrocoll. 2015, 44, 115-121. [CrossRef]

10. Bogaerts, A.; Neyts, E.; Gijbels, R.; Van der, J. Gas discharge plasmas and their applications. Spectrochim. Acta Part B At. Spectrosc. 2002, 57, 609-658. [CrossRef]

11. Ikawa, S.; Kitano, K.; Hamaguchi, S. Effects of $\mathrm{pH}$ on bacterial inactivation in aqueous solutions due to low-temperature atmospheric pressure plasma application. Plasma Process. Polym. 2010, 7, 33-42. [CrossRef]

12. Keidar, M.; Shashurin, A.; Volotskova, O.; Ann, M.; Srinivasan, P.; Sandler, A.; Trink, B. Cold atmospheric plasma in cancer therapy. Phys. Plasmas 2013, 20, 057101. [CrossRef]

13. Lee, H.; Kim, G.; Kim, J.; Park, J.; Lee, J.; Kim, G. Tooth bleaching with nonthermal atmospheric pressure plasma. J. Endod. 2009, 35, 587-591. [CrossRef]

14. Heinlin, J.; Isbary, G.; Stolz, W.; Morfill, G.; Landthaler, M.; Shimizu, T.; Steffes, B.; Nosenko, T.; Zimmermann, J.; Karrer, S. Plasma applications in medicine with a special focus on dermatology. J. Eur. Acad. Dermatol. Venereol. 2011, 25, 1-11. [CrossRef]

15. Osman, A.; Uhlig, H.; Valdes, I.; Amin, M.; Méndez, E.; Mothes, T. A monoclonal antibody that recognizes a potential coeliac-toxic repetitive pentapeptide epitope in gliadins. Eur. J. Gastroenterol. Hepatol. 2001, 13, 1189-1193. [CrossRef]

16. Arentz-Hansen, H.; Mcadam, S.; Molberg, Ø.; Fleckenstein, B.; Lundin, K.; Jørgensen, T.; Jung, G.; Roepstorff, P.; Sollid, L. Celiac lesion T cells recognize epitopes that cluster in regions of gliadins rich in proline residues. Gastroenterology 2002, 123, 803-809. [CrossRef]

17. Morón, B.; Cebolla, A.; Manyani, H.; Alvarez-Maqueda, M.; Megías, M.; Thomas, M.; López, M.; Sousa, C. Sensitive detection of cereal fractions that are toxic to celiac disease patients by using monoclonal antibodies to a main immunogenic wheat peptide. Am. J. Clin. Nutr. 2008, 87, 405-414. [CrossRef]

18. Vader, L.; Stepniak, D.; Bunnik, E.; Kooy, Y.; Haan, W.; Drijfhout, J.; Veelen, P.; Koning, F. Characterization of cereal toxicity for celiac disease patients based on protein homology in grains. Gastroenterology 2003, 125, 1105-1113. [CrossRef]

19. Liu, Z.; Xu, D.; Liu, D.; Cui, Q.; Cai, H.; Li, Q.; Chen, H.; Kong, M. Production of simplex RNS and ROS by nanosecond pulse $\mathrm{N}_{2} / \mathrm{O}_{2}$ plasma jets with homogeneous shielding gas for inducing myeloma cell apoptosis. J. Phys. D Appl. Phys. 2017, 50, 195204. [CrossRef]

20. Shad, A.; Li, C.; Zuo, J.; Liu, J.; Dar, A.; Wang, Z. Understanding the ozonated degradation of sulfadimethoxine, exploration of reaction site, and classification of degradation products. Chemosphere 2018, 212, 228-236. [CrossRef] 
21. Li, Y.; Wang, X.; Yang, H.; Wang, X.; Xie, Y. Oxidation of isoprothiolane by ozone and chlorine: Reaction kinetics and mechanism. Chemosphere 2019, 232, 516-525. [CrossRef] [PubMed]

22. Ghimire, B.; Sornsakdanuphap, J.; Hong, Y.; Uhm, H.; Weltmann, K.; Choi, E. The effect of the gap distance between an atmospheric-pressure plasma jet nozzle and liquid surface on $\mathrm{OH}$ and $\mathrm{N}_{2}$ species concentrations. Phys. Plasmas 2017, 24, 073502. [CrossRef]

23. Liu, F.; Lai, S.; Tong, H.; Lakey, P.; Shiraiwa, M.; Weller, M.; Pöschl, U.; Kampf, C. Release of free amino acids upon oxidation of peptides and proteins by hydroxyl radicals. Anal. Bioanal. Chem. 2017, 409, 2411-2420. [CrossRef] [PubMed]

24. Huang, X.; Kanerva, P.; Salovaara, H.; Sontag-Strohm, T. Degradation of C-hordein by metal-catalysed oxidation. Food Chem. 2016, 196, 1256-1263. [CrossRef] [PubMed]

25. Bruggeman, P.; Schram, D. On OH production in water containing atmospheric pressure plasmas. Plasma Sources Sci. Technol. 2010, 19, 045025. [CrossRef]

26. Pei, X.; Lu, Y.; Wu, S.; Xiong, Q.; Lu, X. A study on the temporally and spatially resolved OH radical distribution of a room-temperature atmospheric-pressure plasma jet by laser-induced fluorescence imaging. Plasma Sources Sci. Technol. 2013, 22, 025023. [CrossRef]

27. Capitelli, M.; Ferreira, C.; Gordiets, B.; Osipov, A. Plasma kinetics in atmospheric gases. Vacuum 2001, 62, 388-389.

28. Liu, D.; Liu, Z.; Chen, C.; Yang, A.; Li, D.; Rong, M.; Chen, H.; Kong, M. Aqueous reactive species induced by a surface air discharge: Heterogeneous mass transfer and liquid chemistry pathways. Sci. Rep. 2016, 6, 23737. [CrossRef]

29. Zangouei, M.; Haynes, B. The Role of Atomic Oxygen and Ozone in the Plasma and Post-plasma Catalytic Removal of $\mathrm{N}_{2} \mathrm{O}$. Plasma Chem. Plasma Process. 2019, 39, 89-108. [CrossRef]

30. Xu, G.; Chance, M. Hydroxyl radical-mediated modification of proteins as probes for structural proteomics. Chem. Rev. 2007, 107, 3514-3543. [CrossRef]

31. Jones, B.; Vergne, M.; Bunk, D.; Locascio, L.; Hayes, M. Cleavage of peptides and proteins using light-generated radicals from titanium dioxide. Anal. Chem. 2007, 79, 1327-1332. [CrossRef] [PubMed]

32. Kato, Y.; Uchida, K.; Kawakishi, S. Oxidative fragmentation of collagen and prolyl peptide by $\mathrm{Cu}(\mathrm{II}) / \mathrm{H}_{2} \mathrm{O}_{2}$. Conversion of proline residue to 2-pyrrolidone. J. Biol. Chem. 1992, 267, 23646-23651. [PubMed]

33. Uchida, K.; Kato, Y.; Kawakishi, S. A novel mechanism for oxidative cleavage of prolyl peptides induced by the hydroxyl radical. Biochem. Biophys. Res. Commun. 1990, 169, 265-271. [CrossRef]

34. Stadtman, E.; Levine, R. Free radical-mediated oxidation of free amino acids and amino acid residues in proteins. Amino Acids 2003, 25, 207-218. [CrossRef] [PubMed]

35. Morgan, P.; Pattison, D.; Davies, M. Quantification of hydroxyl radical-derived oxidation products in peptides containing glycine, alanine, valine, and proline. Free Radic. Biol. Med. 2012, 52, 328-339. [CrossRef] [PubMed]

36. Broeck, H.; Cordewener, J.; Nessen, M.; America, A.; Meer, I. Label free targeted detection and quantification of celiac disease immunogenic epitopes by mass spectrometry. J. Chromatogr. A 2015, 1391, 60-71. [CrossRef]

37. Zhou, L.; Kooy-Winkelaar, Y.M.C.; Cordfunke, R.A.; Dragan, I.; Thompson, A.; Drijfhout, J.W.; Van Veelen, P.A.; Chen, H.; Koning, F. Abrogation of immunogenic properties of gliadin peptides through transamidation by microbial transglutaminase is acyl-acceptor dependent. J. Agric. Food Chem. 2017, 65, 7542-7552. [CrossRef]

38. Peter, H.; Benjamin, L.; Ruby, G. Celiac disease. J. Allergy Clin. Immunol. 2015, 135, 1099-1106.

39. Fatma, B.; Barbara, P.; Andrea, F.; Stefano, S. A complete mass spectrometry (MS)-based peptidomic description of gluten peptides generated during in vitro gastrointestinal digestion of durum wheat: Implication for celiac disease. J. Am. Soc. Mass Spectrom. 2019, 30, 1481-1490.

40. Shi, H.; Cooper, B.; Stroshine, R.; Ileleji, K.; Keener, K. Structures of degradation products and degradation pathways of aflatoxin B1 by high-voltage atmospheric cold plasma (HVACP) treatment. J. Agric. Food Chem. 2017, 65, 6222-6230. [CrossRef]

41. Wieser, H. Chemistry of gluten proteins. Food Microbiol. 2007, 24, 115-1193. [CrossRef] [PubMed]

42. Shewry, P.; Tatham, A. The prolamin storage proteins of cereal seeds: Structure and evolution. Biochem. J. 1990, 267, 1-12. [CrossRef] [PubMed]

43. Nagib, A.; Tifenn, D.; Mohammad-Zaman, N.; Setsuko, K. Tissue-specific defense and thermo-adaptive mechanisms of soybean seedlings under heat stress revealed by proteomic approach. J. Proteome Res. 2010, 9 , 4189-4204. 
44. Martinez-Esteso, M.J.; NøRgaard, J.; Brohée, M.; Haraszi, R.; Maquet, A.; O'Connor, G. Defining the wheat gluten peptide fingerprint via a discovery and targeted proteomics approach. J. Proteom. 2016, 147, 156-168. [CrossRef] [PubMed]

45. Li, M.; Wang, Y.; Ma, F.; Zeng, J.; Chang, J.; Chen, M.; Li, K.; Yang, G.; Wang, Y.; He, G. Effect of extra cysteine residue of new mutant $1 \mathrm{Ax} 1$ subunit on the functional properties of common wheat. Sci. Rep. 2017, 7, 7510. [CrossRef]

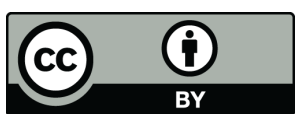

(C) 2020 by the authors. Licensee MDPI, Basel, Switzerland. This article is an open access article distributed under the terms and conditions of the Creative Commons Attribution (CC BY) license (http://creativecommons.org/licenses/by/4.0/). 